
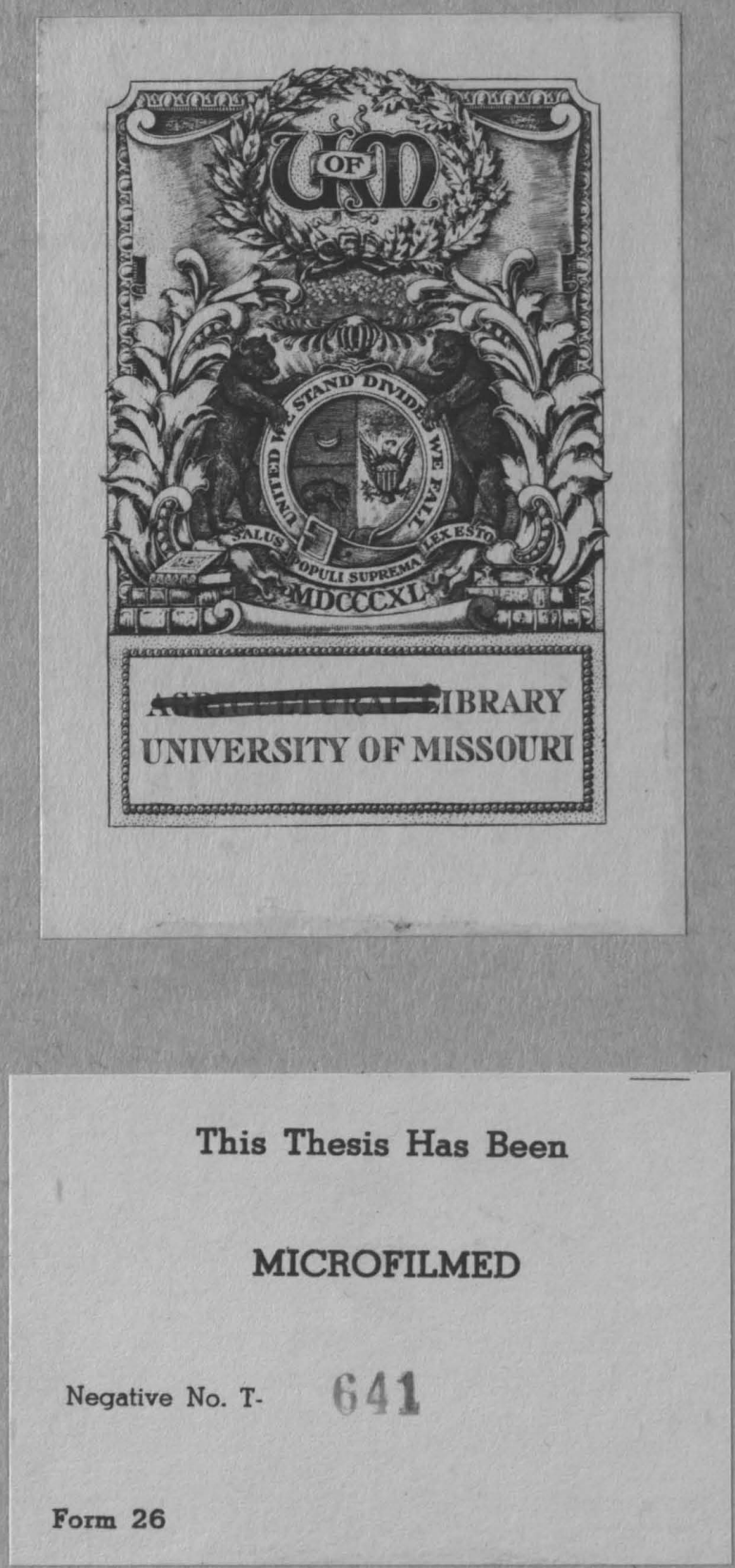






\section{PHYSIOLOGICAL CHANGES OCCURRING IN PLANT TISSUE \\ AS A RESULT OF STIMULI ADMINISTERED \\ TO BREAK THE REST PERIOD}

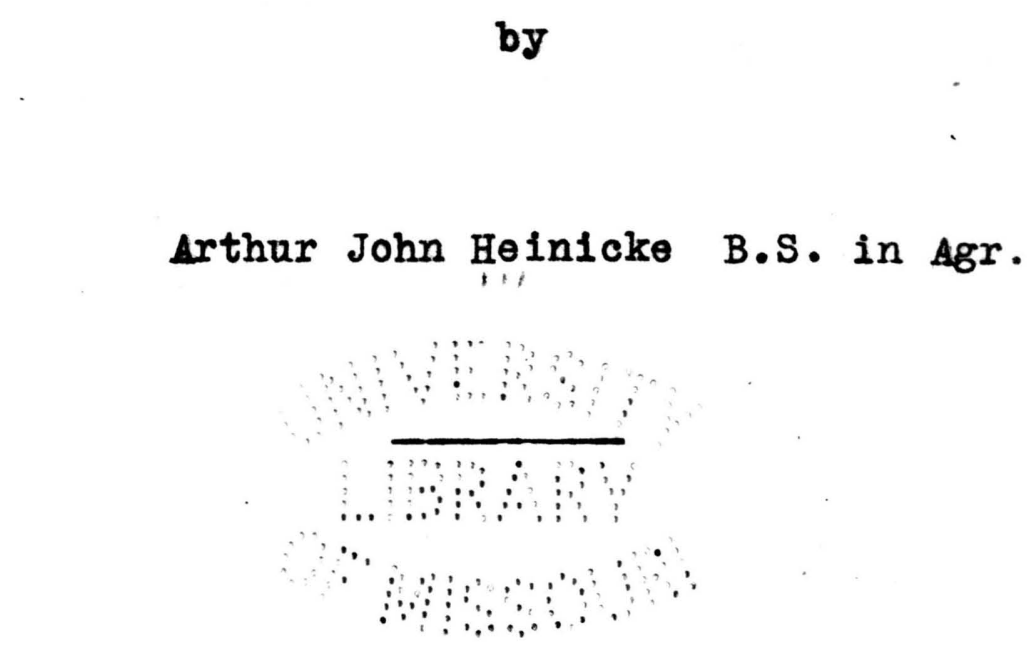

SUBMITTED IN PARTIAL FULFILLMENT OF THE REQUIREMENTS FOR THE DEGREE OF MASTER OF ARTS

in the

GRADUATE SCHOOL

of the

UNIVERS ITY OF MISSOURI

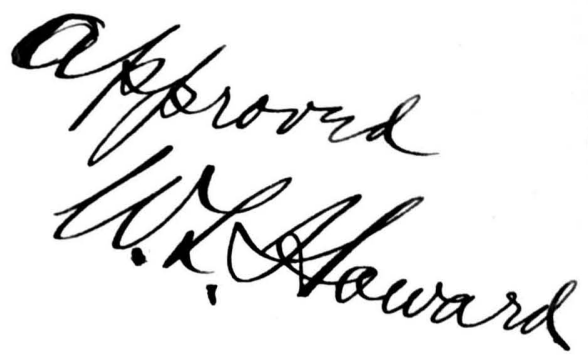



PHYSIOLOGICAL CHANGES OCCURRING IN PLANT TISSUE

AS A RESULT OF STMUULI ADMINISTERED

TO BREAK THE REST PERIOD.

\section{Introduction}

It is a matter of common knowledge that most of our woody plants do not grow continuously throughout the year. The fact is brought to our attention especially in spring, when we may observe the awakening of the vegetation which has been dormant for some time. After the buds open, leaves and twigs continue to grow rather rapidly. Sooner or later, however, vegetative activity diminishes and finally ceases when the terminal buds are formed. The plants are gradually preparing to go into their rest period.

What causes this annual suspension of growth? Is it due simply to the lack of suitable external growth conditions? since the rest period of most of the woody plants happens to fall during winter when temperature and other factors are unfavorable for growth, we are liable to be led to belleve that the annual rest is caused simply by external influences. If 

there is such a simple relation as this between winter and the occurrence of the rest period, then we should not expect plants to suspend vegetative activity if growth conditions remained favorable throughout the year.

But observations and experiments indicate that this is not the case. In many trees, preparation for the rest period begins sometime during sumer, even though all external factors are favorable for growth. Trees, native to our temperate zone, continue to form terminal buds and shed their leaves even though they are grown in some parts of the tropios where temperature and moisture are favorable for continuous growth throughout the jear. (Pfeffer 88).* $\Delta t$ the Missouri Experiment Station, peach, oak, and tulip trees have been growing in a warm greenhouse for at least four year. Each year the trees shed their leaves and become dormant for some time. Howard (47) obtained twigs from a large number of woody plants soon after leaf fall and provided them with warmth and moisture. sbout half of these twigs pushed out their buds. During the first nine days 18 per cent grew. When similar twigs were given the same trestment about two months later, only a small percentage refused to grow. This time, 50 per cent grew during the first nine days.

*See Blbliography at end of paper. 

Incidentally, it may be mentioned that seeds, bulbs and tubers also show a resting period at some stage of their development.

These few citations will be sufficient to show that the relation between the rest period and the environment is not a simple one by any means.

According to Johannsen (53), the influences which bring about the rest are designated as "inner causes." Pfeffer (88) too, speaks of an "autogenic" or self regulated rest. Howard (47, p.14) says, "It is true that the immediate preparation for the winter rest - the formation of terminal buds comes from within, but," he continues, "all of this is the result of habits formed from oft repeated occurrences which are the influencing outward conditions such as the coming of winter." According to this, the plant as we know it, is so organized that it has a tendency to rest regardless of the present environment, but this inner organizationm which is so deeply founded as to be characteristic of the species, is only there as a result of outside conditions which existed some time during the ancestry of the organism. Klebs (56) believes that by using suitable cultural methods, this acquired habit can be broken up in the majority of plants. He bases his belief on experiments in which he has actually succeeded in making Hyacinthus and Ficaria and other plants grow throughout the year, uninterrupted by their usual rest period. 

This brief discussion of the rest period is given only to orientate our subject. A more detailed treatment is to be found in Pfeffer's Pflanzenphysiologie, (88), Johannsen's Aether-Verfahren beim Fruhtreiben (53), and Howard's work on the Winter Rest (47).

For the purposes of this paper, we may define the rest period as "that phase in the development of the plant during which, to all external appearances, the plant becomes incapable of responding to favorable growing conditions." As a result, trees and shrubs stop growth for a time even though temperature and molsture requirements are favorable for continued activity. The rest period is not to be confused with the dormant period. In our climate, the latter begins in autumn when the leaves fall off or die, and it lasts until the buds open in spring. The dormant period is brought about partly by the "voluntary inactivity" - internal - and partly by a "forced inactivity" external -(Johannsen 53, p.9). The latter cause is most influential in very late winter or early spring, at which time many specles of plants have finished their rest period, $1 . e .$, they have regained the capacity to respond to favorable growth conditions, but still no buds are pushed because there is not sufficient warmth for growth to take place

Whatever may be the direct cause of the winter rest period, and whether or not it can be untimately dispensed with, the fact that it can be broken is well established. A 

large variety of agents have been effectively used in breaking the rest period. The influences of high temperature, of freezing and of drying have long been recognized as important factors in bringing about an early growth (Howard 47). Johannsen (53) has succeeded in breaking the rest period of many plants by exposing them to ether or chloroform vapors for twelve to fortyeight hours. Molisch (74) has called attention to the warm water bath as a forcing agent. The same investigator (75) finds that radium emanations are an effective rest period-breaking agent. Jesenko (52) has caused earller growth in woody twigs by immersion in weak alcohol. He obtained similar results by treating with weak acids, such as hyarochloric and tartaric. Weber (105) found that injury induces the resting buds to start into growth. Lakon (65) claims to have gotten earlier bud development by using nutrient salt solutions. Ethyl bromide and other vapors have been used in breaking the rest period by Mocollum (73). Harsberger (39) has found that resting buds which are treated with $\mathrm{NH}_{4} \mathrm{OH}$ grew before untreated buds. Bos (15) has used the galvanic current as a means of arousing the plant from its dormancy. Placing plants in a vacuum, according to Stuart (101) is an effective means of breaking the rest period.

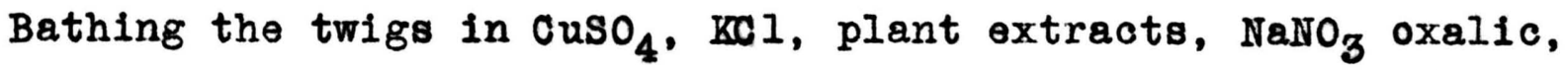
and acetic acid solutions has given somewhat earlier growth of buds so treated. Similar results were obtained by painting the twigs with $\mathrm{MnO}_{2}$. (See latter part of this paper.) 

The effectiveness of these different means of breaking the rest period depends upon the species, as well as upon many other factors, such as time of application, intensity of application, condition of the twig, etc. Some agents cause an earlier growth than others. In general, the intensity of all treatments, 1.e., the concentration of the liquids, the density of the vapors, the duration of application or the degree of heat, etc., must be decreased as the season advances and as the rest perlod approaches its close. Applications which are very effective during December may be very injurious during March.

$\Delta$ striking series of phenomena are certainly presented when such different agencies as intense heat and intense cold, increased and decreased water content, gases and liquids, bases and acids, salts, singly or combined, placing in a vacuum, electricity and injury should have the same ultimate effect of shortening the normal rest period of plants.

How do these various agents affect the physiological processes of the resting tissue? Do all have a similar influ-. ence, or do some bring about growth in one way, e.g., by desiccation and some in another, e.g., by increasing respiration? These were the maln problems suggested to the writer by Dr. W. I. Howard during the summer of 1913. Investigations along the line of these questions have been carried on since the fall of that year, and the results given in the following pages have been obtained during a single season. vonsequently, this thesis 

is in the nature of a preliminary report.

Resumé of Theories Regarding the Influence of Rest Period-Breaking Agents.

Not very much actual experimental work has been done regarding the specific influence exerted by the various agencies used for breaking the rest period. Much has been written, however, regarding the probable action. Claude Bernard (11) thought that etherization caused a coagulation of the protoplasm. Raphael Dubois (30) found an abundant dehydration taking place in plant tissues which were etherized. Johannsen (53, p.57) points out that this dehydration occurs only after the ether has severely injured the tissue. Nevertheless, Dubois' experiments seem to have influenced later authors to accept the theory that otherization and chloroforming have the same influence as drying and freezing - viz. they cause a desiccation of the tissue. Aymard (6) supports this view very vigorously. Stuart (101) too, seems to favor this hypothesis. In speaking of anesthetics he says, "Their effect upon the plant is to arrest growth, extract moisture from the cell protoplasm, and through these physiological derangements imparting a severe shock to the whole plant which when removed causes a decided growth reaction." Similarly, he believes that toxic substances (acetone, alcohol, etc.) and non-toxic agents (freezing, vacuum treatment, desiccetion)"arrest growth and remove moisture from the plant tissue 

much in the same manner as anaesthetics." It is quite apparent that warm water baths which are very useful in shortening the rest do not bring about a drying effect. In this case stuart believes that "hot water imparts a distinct shock to the cell protoplasm and tissue and acts as a solvent in softening up the winter protecting scales inclosing the leaf and flower buds."

Johannsen (53) and Overton (83) have shown clearly that desiccation cannot be caused by the mild doses of ether which are effective in breaking the rest period. Aditional experimental evidence in support of this fact is given in the latter part of this paper.

Johannsen (53, p.49) believes that etherization may either affect the vegetative activity, or it may influence the obstacles or inhibiting factors of growth. He explains that small amounts of ether would be apt to favor vegetative actirity, while larger doses, such as are given when the rest period is to be broken, weaken or devitalize those favtors which are inhibiting growth, and thereby indirectly favor vegetation.

According to Drude, Nauman and Ledieu (29a) the effect of ether and chloroform is that they check some of the changes within the plant coll, while at the same time increasing respiration. Muller-Phurgau (77a) has demonstrated that potatoes placed in cold will become richer in sugar. Beltz (10) is of the opinion that ether and chloroform bring about an enlargement of the cell similar to that occurring in springtime. Molisch (74) 

points out that the warm bath has to do with high temperature, inhibition of respiration under water, prolonged contact with water, imbibing of water into the plant which facilitates the diosmosis of substances in the cells and tissues. Iraklionow (48) believes that, by means of the warm water bath the resting mechanism of growth is set in motion through the removal of a catch. As a result of this release,pro-ferments are brought into an active condition. These liberated enzymes then function as a lubricant which hastens the reactions necessary for life. Klebs (57) holds that during the rest period, we have an accumulation of organio foods which have been assimilated after length growth has been suspended, but while the leaves were still active. He says, "From this view point, we can argue that every rest period must allow itself to be broken since it depends upon regeneration of fermentative activity." He points out that a combination of high temperatures and humidity favor fermentation; and he thinks it probable that the influences of ether can be traced to this factor. He made no direct experiments to prove his statements.

In this connection, the statement of Fisher (34) is of interest. He claims that the resting buds of trees cannot be made to grow until a certain minimum of the insoluble starch has been changed"to easily respired and therefore energy yielding material." Johannsen and Pfeffer, however, do not seem to think that the presence of sugar is the determining 

factor.

This review will give some idea of the theories that have been, and are still held regarding the manner in which the rest period-breaking agents accomplish their work. It might be well to mention a few observations regarding the physiological effects of ether and other agents on active tissue.

Gerrassimow (35a) finds that ether causes increased growth of Spyrogyra due to a stimulation of the cell nucleus. Iatham (65a) finds an increased economy in the metabolism after increased growth of chloroformed fungi. According to Butkewitsch (17) ether vapor dissolves starch in the leaves. Lepeschkin (67) has found that the osmotic pressure of spyrogyra cells which remained in .05 per cent to 1 per cent chloroform or in $2 \frac{1}{2}$ per cent ether solutions for some time was increased by 0.1 to 0.5 atmospheres. Zaleski (II2) has shown that etherization increases the protein regeneration in the cotyledon of Iupinus seedlings. It diminishes the loss of glucose and causes a greater movement from endosperm into the growing plant. These findings are of interest since they suggest some of the probable effects of rest period breaking agents.

Normal Processes of Resting Tissue.

By first considering the normal physiological behavior of the resting tissue, we will have a more comprehensive background for the discussion and understanding of "abnormal" physiological processes such as those produced by the various 

means used to break the rest period.

4 "resting" plant is by no means inactive. Cuttings made in winter will form callus tissue even though the buds are incapable of growing. The reserve substances of trees undergo very extensive changes during the course of the winter. Fisher's (34) investigations illustrate this transformation very nicely. In autumn, the parenohyma is filled with starch. During late autumn this starch changes to fats and, in part, to glucose. In some cases, this change occurs in the cortex only, the starch in the remaining tissue being unchanged; in other cases, no starch can be found during mid-winter. Starch ispre-formed during early spring, and soon reaches a maximum as high as in autumn. When the buds open the starch is again dissolved to be used in building up new tissue. The reserve food in the buds also undergoes a marked change. Part of it is transferred to the embryonic organs which at first were free from starch. The quantitative analyses of Castanea wood which were made by Leclerc du Sablon substantiate these observations. He found that the sugar content in october was 2.2 per cent. By February it had increased to 4.3 per cent. A month later the quantity of sugar was again reduced to 2.7 per cent. Chander (20) finds the greatest amount of dextrose in apple twig sap in December. The sap becomes poorer and poorer in sugar until in May. 

Since the resting plant carries on reproductive and chemical activity, we would expect that it also respires. The subsequent experiments throw light on the normal as well as stimulated respiration. In general, the respiratory activity is diminished during the resting period as we might expect; still $\mathrm{CO}_{2}$ production goes on at all times.

Hence, we can see that the rest period is not a stage of complete inactivity. Many physiological functions continue. Their activity, however, is reduced and is also dependent upon external conditions to some extent.

MXPER TMENT AL WORK, 1913-14.

A. Respiration Experiments.

It has been known for some tine that anaesthetics and "poisons" in general stimulate the respiratory processes of plants. Iikewise mechanical injury, high temperature and other agents are known to bring about greater $\mathrm{CO}_{2}$ production. This is true of resting as well as active tissue. (Simon, 99; Iraklionow, 48; Butler, 19, and many others). Object of the Experiments.

During our studies, additional respiration experiments were carried out with the following objects in view:

1. To determine the effect of previous drying and of previous freezing on the $\mathrm{CO}_{2}$ production of dormant apple twigs.

2. To determine the influence of the same dose of ether on the $\mathrm{CO}_{2}$ production of dormant twigs of different species. 

3. To determine the effect of the same dose of ether on the $\mathrm{CO}_{2}$ production of dormant apple twigs at different times during the season.

Method of Collecting Material.

The importance of obtaining representative material and uniform lots for comparative experiments cannot be overemphasized. The plan of securing twigs for the experiments was as follows: In all cases, one year old twigs, i.e., the growth which had been made during 1913, were used. This material had been exposed to the environment the shortest time, and hence had not had as much chance to become altered in one way or another as older material. The twigs used were fully matured, each specimen having formed a normal terminal bud. They were taken from the tops of the trees where all had the same exposure to sunlight and other conditions. Only those twigs which had made from 20 to $30 \mathrm{~cm}$. growth were collected. They were cut from the tree just above the last annual ring. In case twigs were obtained from more than one tree, the material from each tree was kept separate until divided into lots. Whenever a series of comparative experiments were to be made, the material was secured from the same trees, and just as much was taken from every tree as was used from that particular treo in the other tests. For example, suppose material was secured from trees Nos. 1, 2, 3, etc., each tree jlelding 50 twigs. If the same experiment was to be repeated a few weeks later, 50 twigs would be collected 

from each of trees Nos. 1, 2, 3, etc.

After the material was secured, the samples from each were divided into similar lots in the following manner; all the out surfaces of the twigs were placed down, the terminal buds up. The bunch of twigs was held loosely between the hands, and then jolted up and down on the table until all cut ends stood on the same level. Then the lot was held with one hand, and with the other, the twigs were distributed one at a time commencing with the longest and ending with the shortest. If the material from each tree was divided among six lots, Nos. 1,$2 ; 3,4,5$ and 6, then No. I would get the first twig, and No. 6 , the sixth; the serenth twig would go to No. 6 and the twelfth and thirteenth to No. 1, etc. When the material from the second tree was distributed, No. 6 received the first and No. I the sixth and seventh, etc. The material from each tree was distributed in a similar manner. In the end, these composite samples were very similar to each other. Each contained the same number of twigs; each had just as many twigs from any single tree as the other; and overy lot had just as many long and just as many short twigs as the other. The efficiency of this method of distribution was shown by the fact that the weights of the composite samples obtained in this way never varied more than 2 or 3 per cent. Incidentally, 1twas important to have the same number of twigs in each lot, because each twig had received a wound and wounding effects respiration. Although other precautions were taken to 

rate 2.

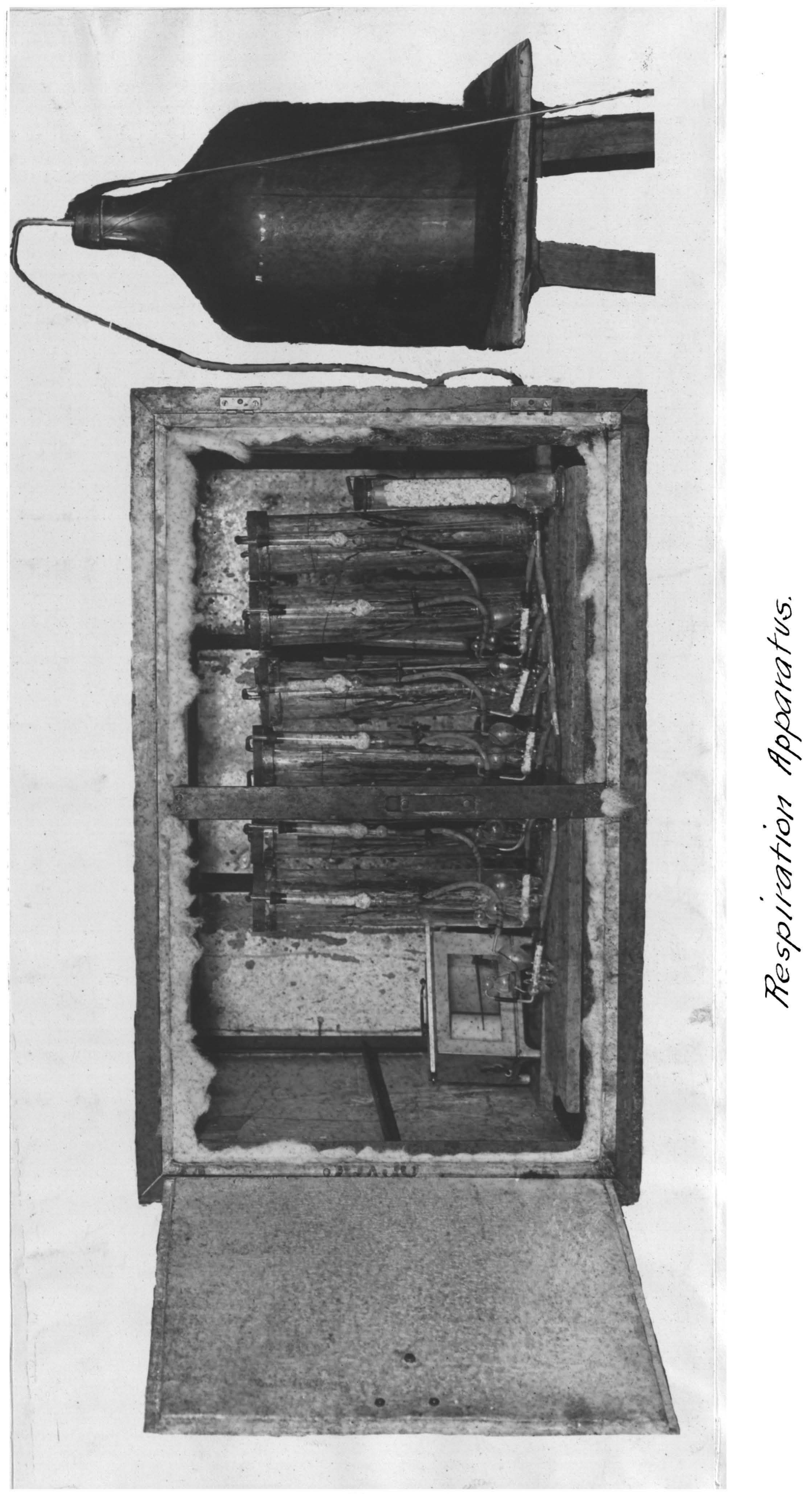





\section{Plate 2 .}

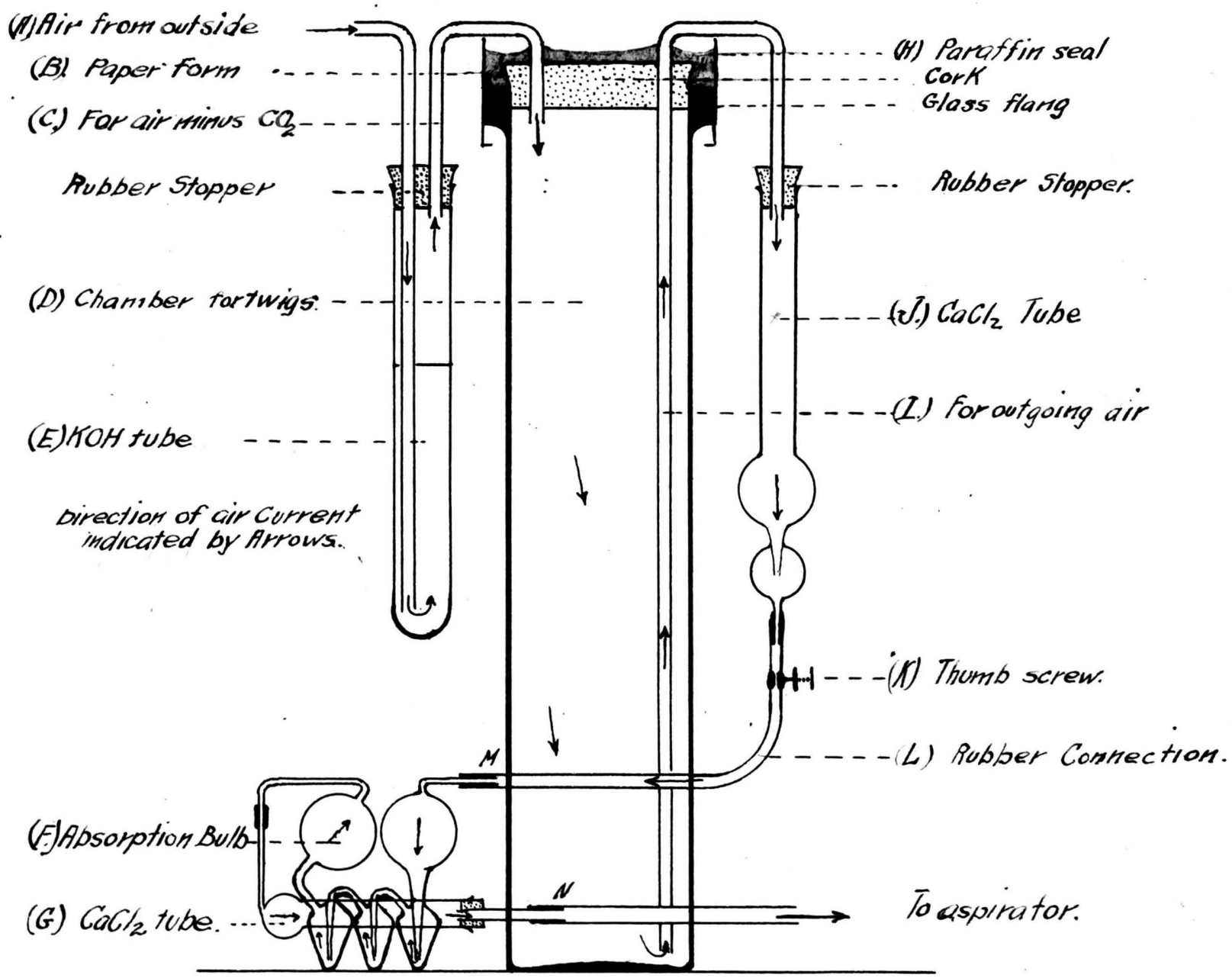

\section{Respiration Chamber x $1 / 4$}



offset the effect of this wounding, still if the precautions were not entirely adequate, then the effect on respiration by the injury would be the same in all lots, and the results would still be comparative.

\section{Apparatus.}

The general appearance of the apparatus used for the determination of the $\mathrm{CO}_{2}$ production of the twigs, is shown in the photograph on plate I. The respiration chambers proper consisted of six slender specimen jars. Each chamber with its accompanying parts formed a single unit. The diagram on plate 2 illustrates in detail the construction of one of these units. The chamber "D" had a capacity of 2.5 liters. Before the air entered this chamber, it was freed from $\mathrm{CO}_{2}$ by passing through the saturated solution of $\mathrm{KOH}$ in tube "E". It left the chamber, together with the $\mathrm{CO}_{2}$ produced by the twigs, through the glass tube I which opens at bottom of the jar. The moisture was taken up by the $\mathrm{CaCl}_{2}$ in tube "J". The $\mathrm{CO}_{2}$ produced by the twigs was absorbed by the saturated solution of $\mathrm{KOH}$ in the Geissler bulbs "F". $\quad \mathrm{CaCl}_{2}$ tube "G" retained all moisture which evaporated from the bulbs.

In setting up the apparatus, the weighed twigs were placed in chamber $D$, after which the two-hole cork was inserted. Then the glass rods for the incoming and for the outgoing air were passed through the cork. The $\mathrm{KOH}$ and the $\mathrm{CaCl}_{2}$ tubes were connected to the respective glass tubes. After this a strip of 

heavy paper (B) $6 \mathrm{~cm}$. wide, was tightly wrapped around the glass flange at the top of the jar. This paper form was held firmly by means of a rubber band. Melted paraffin was then poured over the cork to a depth of from 1 to $2 \mathrm{~cm}$. This sealed all possible openings through which air might leak.

The absorption bulbs were connected at $M$ and $N$ by means of rubber tubing. They were weighed on a delicate balance. After all units were set up in a similar manner, they were connected to the same sensitive system. The air was drawn through each chamber at an average rate of 3 liters per hour, the flow being regulated by means of the thumb screw at $\mathrm{K}$ (plate 2 ). Each day the air contained in every unit was renewed eight times, which proved by experiment, to be sufficient to obtain all $\mathrm{CO}_{2}$ produced by the twige during the twenty-four hours. Suction was provided by a large aspirator bottle. This bottle had a capacity of 45 liters. Just before the air entered the water bottle, it passed through a $\mathrm{CaCl}_{2}$ tower. The $\mathrm{CaCl}_{2}$ retained all moisture which came from the bottle, and which, if not removed, would be taken up by the $\mathrm{CaCl}_{2}$ tubes attached to the absorption bulbs, thereby increasing their weight unduly.

The entire apparatus, excepting the aspirator, was placed in a large double-walled box made of heavy galvanized iron (Plate I). The space between the two walls $(5 \mathrm{~cm}$.$) was filled$ with water which was running in and out continually. The doors were also double-walled but they contained no water. The edges 



\section{Plate 3}

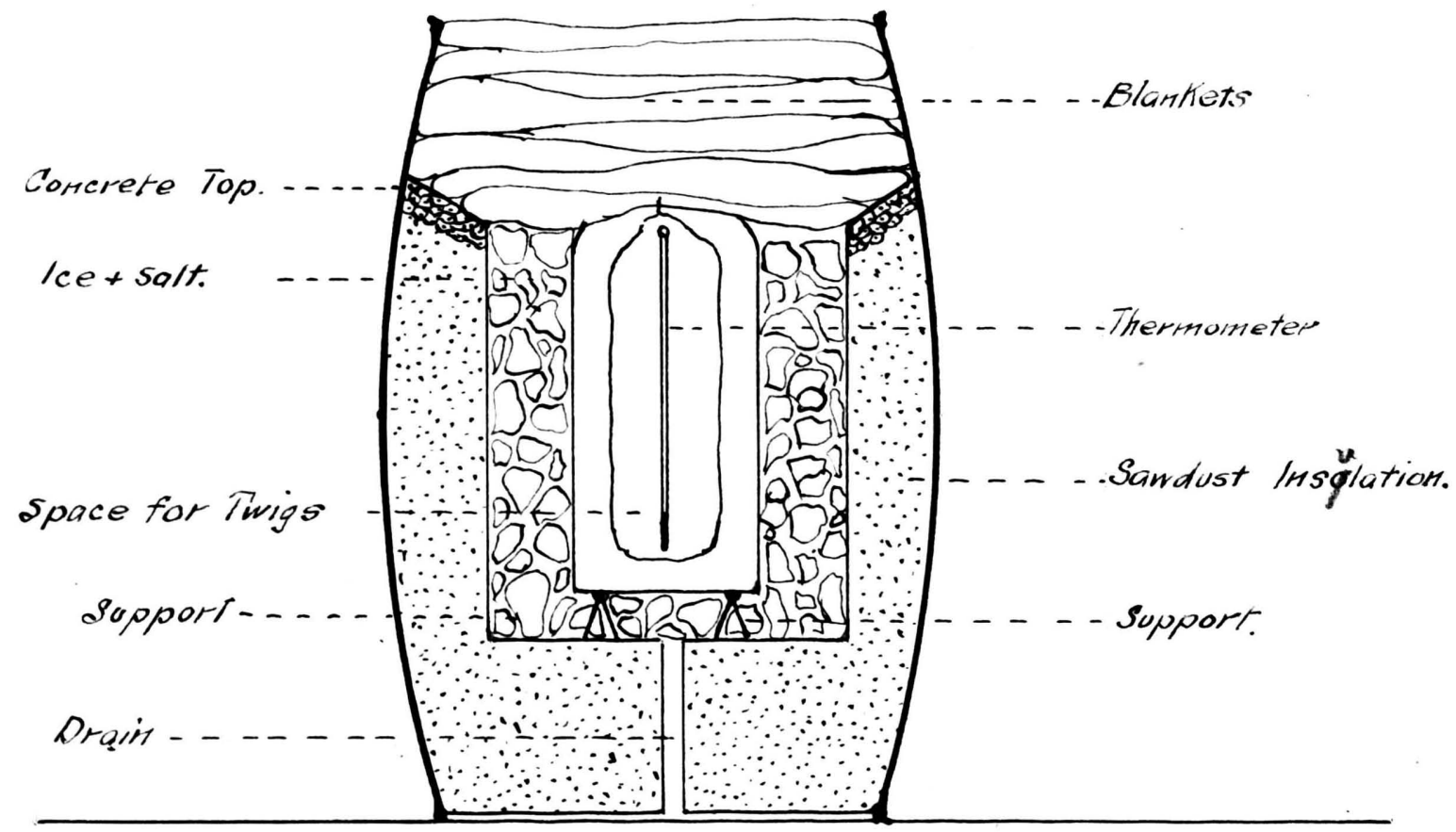

Freezer.

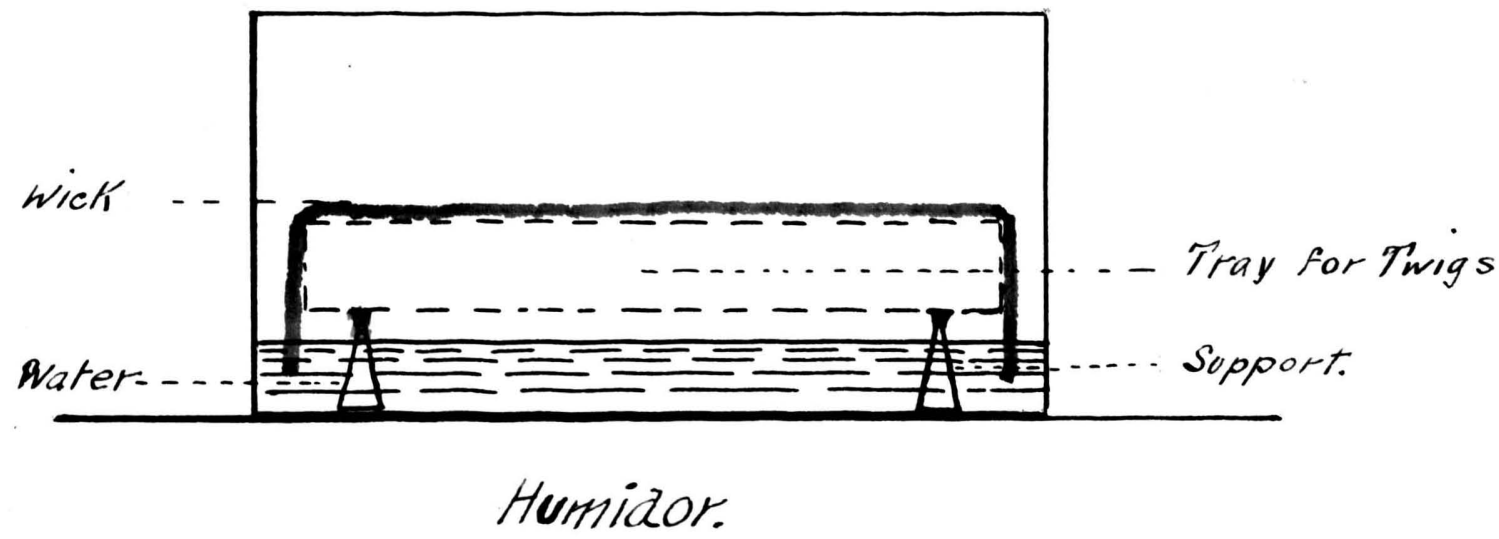



of the doors were lined with cotton so they would fit tightly and thereby prevent exchange of air of different temperatures. The box was placed in a cool north basement room.

A self-recording thermograph within the box showed an almost horizontal line from day to day. The thermometer registered between $15^{\circ}$ and $18^{\circ} \mathrm{C}$.

1. $\mathrm{CO}_{2}$ Production of Twigs as Influenced by Provious Drying and by Freezing.

On Feb. 14, 1914, twigs from three King David apple trees were collected and divided in the manner described above. Two lots were placed in a freezing apparatus as shown in the diagram, plate 3. The temperature was kept at $-15^{\circ}$ to $-19^{\circ} \mathrm{C}$. Two lots were placed in a humidor at room temperatures, $18^{\circ}-21^{\circ} \mathrm{C}$. (See diagram, plate 3). Two lots were placed on top of a book case where the room temperature varied between $26^{\circ}$ and $31^{\circ} \mathrm{C}$. In all cases the preliminary treatment lasted sixty hours. Before putting in the respiration chamber, the dried twigs were allowed to regain turgidity, by immersing them in water for several hours. During thettime, they imbibed enough moisture to bring them up to within 5 per cent of their original weight.

The data of this experiment are summarized in table No. 3, page 18 . The dates show when the material was collected. Calculations of $\mathrm{CO}_{2}$ production are based on the weights of the twigs just before they were put in the respiration chambers. If the calculations had been made on fresh weight, the results would 

Table No. 3

$\mathrm{CO}_{2}$ Produced by Moist, by Dried and by Frozen King David Apple Twigs at $15-18^{\circ} \mathrm{C}$.

\begin{tabular}{|c|c|c|c|c|c|c|c|}
\hline \multirow[t]{2}{*}{ Date } & \multirow[t]{2}{*}{ Treatment } & \multirow[t]{2}{*}{$\begin{array}{l}\text { Av. Wt. } \\
\text { Fresh Twigs }\end{array}$} & \multirow{2}{*}{$\begin{array}{l}\mathrm{H}_{2} 0 \text { lost } \\
\text { during } \\
\text { Treatment }\end{array}$} & \multicolumn{4}{|c|}{$\begin{array}{c}\mathrm{CO}_{2} \begin{array}{l}\text { Production in } \mathrm{Mg} \text {. per } \mathrm{hr} . \\
\text { per } 100 \mathrm{gr} \text {. twigs. }\end{array}\end{array}$} \\
\hline & & & & Ist da. & 2nd da. & 3rd da. & 4 th da. \\
\hline $2 / 14$ & Moist & $116.1 \mathrm{gr}$. & $3.9 \%$ & 2.79 & 3.57 & 2.73 & 1.83 \\
\hline $2 / 14$ & Dried & 117.0 & 22.6 & 8.56 & 10.34 & 6.43 & 4.39 \\
\hline $2 / 14$ & Frozen & 115.9 & 1.8 & 12.16 & 8.65 & 4.74 & 3.84 \\
\hline
\end{tabular}

Table No. 4

Ratio of $\mathrm{CO}_{2}$ Produced by Treated to $\mathrm{CO}_{2}$ Produced by lioist Twigs.

\begin{tabular}{|l|c|c|c|c|}
\hline & Ist da. & 2nd da. & 3rd da. & 4 th da. \\
\hline Dried & 3.07 & 2.89 & 2.36 & 2.40 \\
\hline Froist & 4.36 & 2.42 & 1.73 & 2.10 \\
\hline
\end{tabular}



have been affected relatively little. It should be kept in mind that while the dry twigs had lost nearly one-fourth of their welght, yet this was made up again before putting the material in the chamber. The KOH bulbs were weighed every twenty-four hours and from this the results were reduced to a one hour basis. Results of Respiration Tests.

The figures show that the frozen twigs produced more $\mathrm{CO}_{2}$ during the first day than either the dried or the moist material. After that the dried twigs took the lead. Both the moist and the dry twigs produced more $\mathrm{CO}_{2}$ the second day than the first, but the frozen twigs produced less. After the second day, the respiratory activity diminished in all cases.

Table No. 4, page 18, gives the ratio of the $\mathrm{CO}_{2}$ produced by the treated to the $\mathrm{CO}_{2}$ produced by the moist twigs. The figures are obtained by dividing the amount of $\mathrm{CO}_{2}$ produced per $100 \mathrm{gr}$. treated twigs, per hour, by the amount of $\mathrm{CO}_{2}$ produced by $100 \mathrm{gr}$. untreated or molst twigs per hour.

During the first day, the frozen twigs produced over four times as much $\mathrm{CO}_{2}$ per hour, per $100 \mathrm{gr}$. of twigs as the twigs kept molst. The dry twigs gave off three times as much. The ratios fell on the second and third days in both cases; but on the fourth day they rose again. These figures show that the decline in the respiratory activity of the twigs kept moist went on more slowly and more uniformly than either of the treated sets. The figures also show that the respiration of the dried twigs 

noticeably decreased day by day, while respiratory activity of the frozen material was not nearly so marked on the third day as it was on the first two days.

In this connection it should be mentioned, that all buds on the twigs which were given the preliminary treatment as above and then placed in beakers of water in the greenhouse, burst within a few weeks. The frozen twigs were a little ahead of the dried in beginning growth and both were about one week ahead of those that were untreated. 2. CO$_{2}$ Produced by Etherized and by Untreated Twigs of Different Species.

The species used in these experiments were Pyrus Malus var. Jonathan, Fraxinus Ornus Iinn., Quercus coccinea Muench, and Morus alba. One year old wood from young vigorous trees was used in all cases. The twigs were collected and then divided into similar lots as described previously. Preliminary treatment was carried out in the following manner. Three of the lots were placed in a 14 liter specimen jar (Plate 4). The remaining three were placed in a similar jar. These vessels were provided with screw clamp lids and rubber washers by means of which the jars could be made alr tight. Just before fastening the lid of one of the jars, ether, used at the rate of 0.5 co. per liter of space, was poured in. The lid was then screwed on immediately. The other jar was closed up without adding any ether. Both vessels were kept side by side for twenty-four hours at a temperature of 

Plate 4

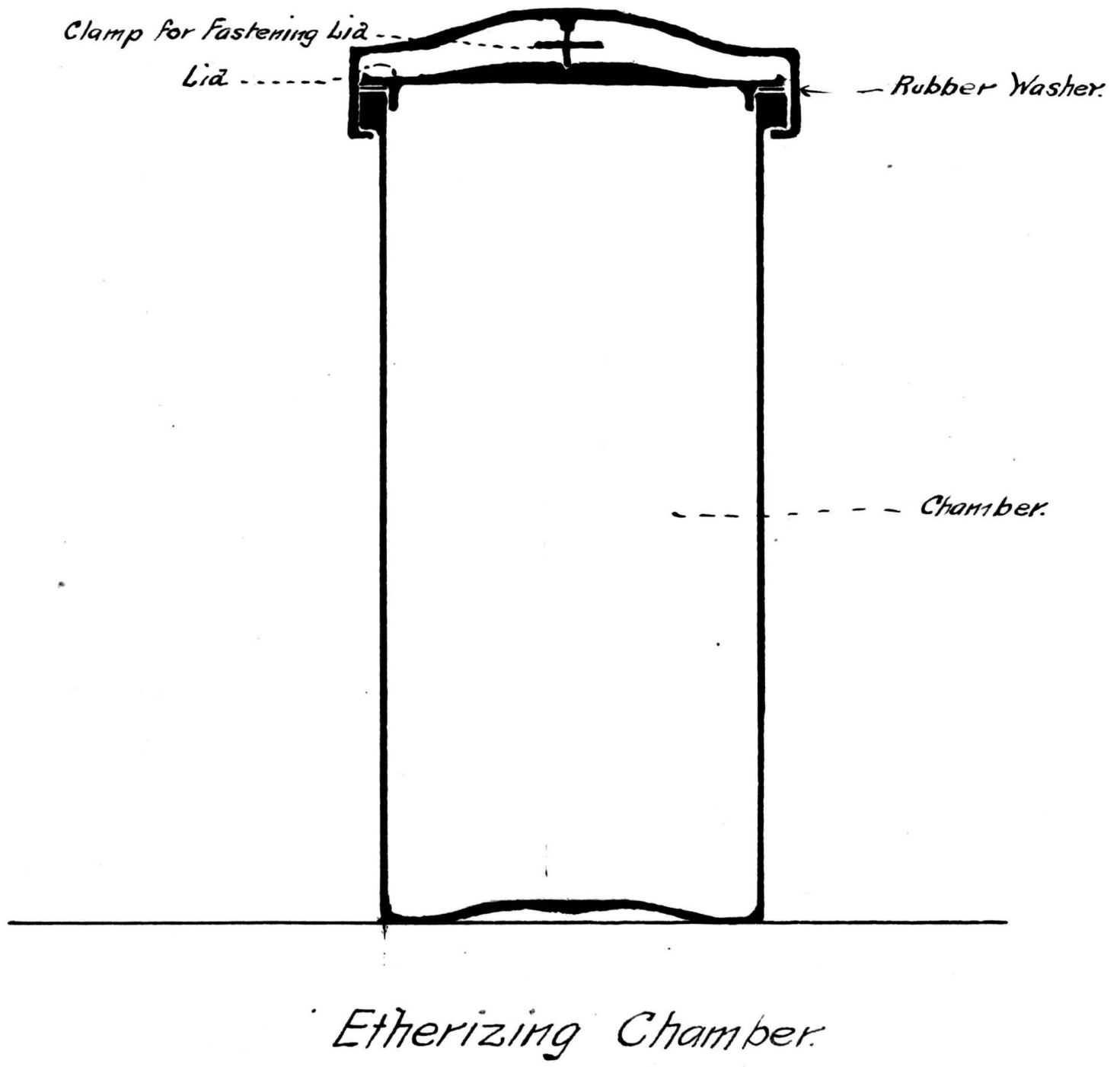



$20^{\circ} \mathrm{C}$

since neither jar contained water, no allowance had to be made for absorption of ether by water. (Johannsen 53, p.20). The absence of water gave the cut ends of the twigs a chance to become dry and plugged up. This no doubt tended to minimize though not to entirely do away with, the effect of injury on respiration. However, since the same number of twigs were contained in each lot, error from this source would be the same in all cases and hence its influence would not affect the comparative value of the results.

The moisture lost during this preliminary treatment was practically the same in both etherized and unetherized material; the amount lost never exceeded 0.5 of 1 per cent. (Cf. data, table 5, page 22). Whatever moisture is lost, is that of transpiration.

Ss soon as the preliminary treatment was over, the twigs were placed in the respiration chamber and $\mathrm{CO}_{2}$ determinations began. The results obtained are summarized in table No. 5, page 22. The dates, as before, show when the twigs were collectod. Calculations are based on the fresh weight which is practically the same as the weight after the preliminary treatment. The KOH bulbs were welghed once every twenty-four hours. Discussion of Results.

From the data, we can see that the normal respiration of different species varies greatly, being most vigorous in the 

Table No. 5

$\mathrm{CO}_{2}$ Produced by Etherized and Untreated Twigs of Different Species, at $15-18^{\circ} \mathrm{C}$.

\begin{tabular}{|c|c|c|c|c|c|}
\hline \multirow[t]{2}{*}{ Date } & \multirow[t]{2}{*}{ Species } & \multirow[t]{2}{*}{ Treatment } & \multicolumn{3}{|c|}{$\begin{array}{l}\text { COQ Production in } \mathrm{Mg} \cdot \mathrm{per} \\
100 \mathrm{gr} \text {. twigs }\end{array}$} \\
\hline & & & Ist da. & 2nd da. & $3 r d \mathrm{~d} a$ \\
\hline $1 / 7$ & Pyrus malus var. Jonathan & \begin{tabular}{|l|} 
Etherized \\
Untreated
\end{tabular} & $\begin{array}{r}19.51 \\
6.55\end{array}$ & $\begin{array}{r}12.01 \\
3.51\end{array}$ & $\begin{array}{l}9.39 \\
2.65\end{array}$ \\
\hline $1 / 13$ & Fraxinus Ornus, (Iinn.) & \begin{tabular}{|l|} 
Etherized \\
Untreated
\end{tabular} & $\begin{array}{l}4.76 \\
3.60\end{array}$ & $\begin{array}{l}7.15 \\
6.27\end{array}$ & $\begin{array}{l}4.76 \\
3.57\end{array}$ \\
\hline $1 / 19$ & Quercus coccinea (Muench) & \begin{tabular}{|l} 
Btherized \\
Untreated
\end{tabular} & $\begin{array}{r}14.29 \\
8.35\end{array}$ & $\begin{array}{l}9.24 \\
4.60\end{array}$ & $\begin{array}{l}7.83 \\
4.01\end{array}$ \\
\hline $1 / 23$ & Morus alba (Iinn.) & \begin{tabular}{|l} 
Etherized \\
Untreated
\end{tabular} & $\begin{array}{l}41.19 \\
17.52\end{array}$ & $\begin{array}{l}25.77 \\
12.15\end{array}$ & $\begin{array}{r}14.09 \\
8.03\end{array}$ \\
\hline
\end{tabular}

Table No. 6

Ratio of $\mathrm{CO}_{2}$ Produced by Etherized, to $\mathrm{CO}_{2}$ Produced by Untreated Twigg.

\begin{tabular}{|l|c|c|c|}
\hline & lst da. & 2nd da. & 3rd da. \\
\hline Pyrus malus & 2.98 & 3.43 & 3.54 \\
Praxinus ornus & 1.32 & 1.14 & 1.33 \\
Quercus cocoinea & 1.71 & 2.01 & 1.95 \\
Morus alba & 2.39 & 2.12 & 1.75 \\
\hline
\end{tabular}



mulberry, next highest in the oak and least in case of the ash and apple. In all cases, etherization causes an increased production of $\mathrm{CO}_{2}$. The relative amount of increase, however, varies with the different species, as may be seen by comparing the ratios given in table No. 6. These ratios are obtained as previously explained.

The figures show that the stimulating effect of ether is most marked in case of the apple, the etherized material heving produced over three times as much $\mathrm{CO}_{2}$ as the untreated. The ratios increase from the first until the third day. In mulberry, etherization does not cause such a great increase in $60_{2}$ production as in the apple, but it has a greater effect than in case of ash and oak. The increase is greatest during the first day after which it becomes less noticeable.

The respiration of oak twigs is affected less by etherization than that of either apple or mulberry. The stimulation seems to increase from the first to the third day.

Etherized ash twigs do not give off very much more $\mathrm{CO}_{2}$ than untreated twigs.

In all cases etherized and untreated twigs were placed In the greenhouse in beakers of water where they were allowed to grow. The treated apple buds came out over one week before the untreated; in the case of the mulberry, the etherized buds came out several days before the untreated, but they soon stopped growing, allowing the untreated buds to overtake them. The etherized 

and untreated oak and ash buds opened about the same time. Treatment apparently had no effect.

It will be seen that the species in which CO${ }_{2}$ production was stimulated most by etherization, opened their buds before the untreated. When the stimulation continues to increase for several deys, no reaction sets in in the development of the young growth; but when the stimulation declines very quickly, a reaction does occur; when respiration is not stimulated very much, the treatment has little effect in causing the buds to open earlier.

3. COO $_{2}$ Produced by Ftherized and by Untreated Apple Twigs at Different Times During the Season.

The material for this series of experiments was secured from a number of similar vigorous 15 year old Jonathan apple trees which were growing in the Experiment station orchard at Columbia, Mo. The twigs were collected and divided into similar lots as previously described. The lots contained about 40 twigs each. They weighed about 150 grams.

The preliminary treatment with ether was carried out in the same way as described for the previous experiment. Immediately after the preliminary treatment, the material was put in the chambers and $\mathrm{CO}_{2}$ determinations began at once.

The results of these determinations are given in table NO. 7, page 25. The dates, as before, show when the material was collected. Calculations are based on the fresh weight of the 

Table No. 7

$\mathrm{CO}_{2}$ Produced by Etherized and by Untreated Jonathan Apple Twigs at Various Times During the Dormant Season. Temperature $15-18^{\circ} \mathrm{C}$.

\begin{tabular}{|c|c|c|c|c|c|c|c|}
\hline \multirow[t]{2}{*}{ Date } & \multirow{2}{*}{ Treatment } & \multicolumn{6}{|c|}{$\mathrm{CO}_{2} \begin{array}{l}\text { Production in } \mathrm{Mg} . \\
\text { per } 100 \mathrm{gr} .\end{array}$} \\
\hline & & lst. da & 2nd da. & $3 r d d a$. & 4th da. & 5 th da. & 6 th da \\
\hline $10 / 23$ & $\begin{array}{l}\text { Etherized } \\
\text { Untreated }\end{array}$ & $\begin{array}{r}10.40 \\
8.38\end{array}$ & $\begin{array}{l}5.72 \\
5.17\end{array}$ & $\begin{array}{l}3.50 \\
3.19\end{array}$ & $\begin{array}{l}2.96 \\
2.77\end{array}$ & -- & -- \\
\hline $11 / 26$ & $\begin{array}{l}\text { Etherized } \\
\text { Untreated }\end{array}$ & $\begin{array}{l}31.36 \\
19.91\end{array}$ & $\begin{array}{r}13.52 \\
5.31\end{array}$ & $\begin{array}{l}8.37 \\
3.10\end{array}$ & $\begin{array}{l}7.22 \\
3.13\end{array}$ & $\begin{array}{l}5.24 \\
2.30\end{array}$ & $\begin{array}{l}3.70 \\
2.31\end{array}$ \\
\hline $1 / 8$ & $\begin{array}{l}\text { Etherized } \\
\text { Untreated }\end{array}$ & $\begin{array}{r}19.51 \\
6.55\end{array}$ & $\begin{array}{r}12.01 \\
3.51\end{array}$ & $\begin{array}{l}9.39 \\
2.65\end{array}$ & $\overline{-}-$ & $\begin{array}{l}5.31 * \\
2.12^{*}\end{array}$ & $\begin{array}{l}4.87 \\
1.75\end{array}$ \\
\hline $2 / 9$ & $\begin{array}{l}\text { Etherized } \\
\text { Untreated }\end{array}$ & $\begin{array}{r}20.33 \\
8.75\end{array}$ & $\begin{array}{r}13.64 \\
6.05\end{array}$ & $\begin{array}{l}8.23 \\
8.79\end{array}$ & $\begin{array}{l}5.59 \\
3.87\end{array}$ & $\begin{array}{l}1.39 \\
2.46\end{array}$ & $\begin{array}{r}.57 \\
2.41\end{array}$ \\
\hline $3 / 8$ & $\begin{array}{l}\text { Etherized } \\
\text { Untreated }\end{array}$ & $\begin{array}{r}81.89 \\
7.52\end{array}$ & $\begin{array}{r}13.18 \\
5.61\end{array}$ & $\begin{array}{l}7.37 \\
4.42\end{array}$ & $\begin{array}{l}2.03 \\
4.55\end{array}$ & $\begin{array}{l}1.25 \\
5.06\end{array}$ & $\begin{array}{r}.72 \\
4.57\end{array}$ \\
\hline
\end{tabular}

*Average for 4 th and 5 th days.

Table No. 8

Ratio of $\mathrm{CO}_{2}$ Produced by Etherized, to $\mathrm{CO}_{2}$ Produced by Untreated Twig's.

\begin{tabular}{|c|c|c|c|c|c|c|c|}
\hline Date & Ist da. & 2nd da. & 3rd da. & 4th da. & 5th da. & 6th da. & Average \\
\hline $10 / 23$ & 1.24 & 1.10 & 1.09 & 1.07 &.-- &.-- & 1.13 \\
$11 / 26$ & 1.58 & 2.55 & 2.71 & 2.31 & 2.28 & 1.60 & 2.17 \\
$1 / 8$ & 2.98 & 3.43 & 3.54 &.-- & $2.50 *$ & 2.78 & 3.05 \\
$2 / 9$ & 2.32 & 2.25 & 2.17 & 1.45 & .56 & .23 & 1.48 \\
$3 / 8$ & 2.91 & 2.35 & 1.67 & .45 & .25 & .16 & 1.30 \\
\hline
\end{tabular}

*4th and 5 th day. 



\section{plate 5.}

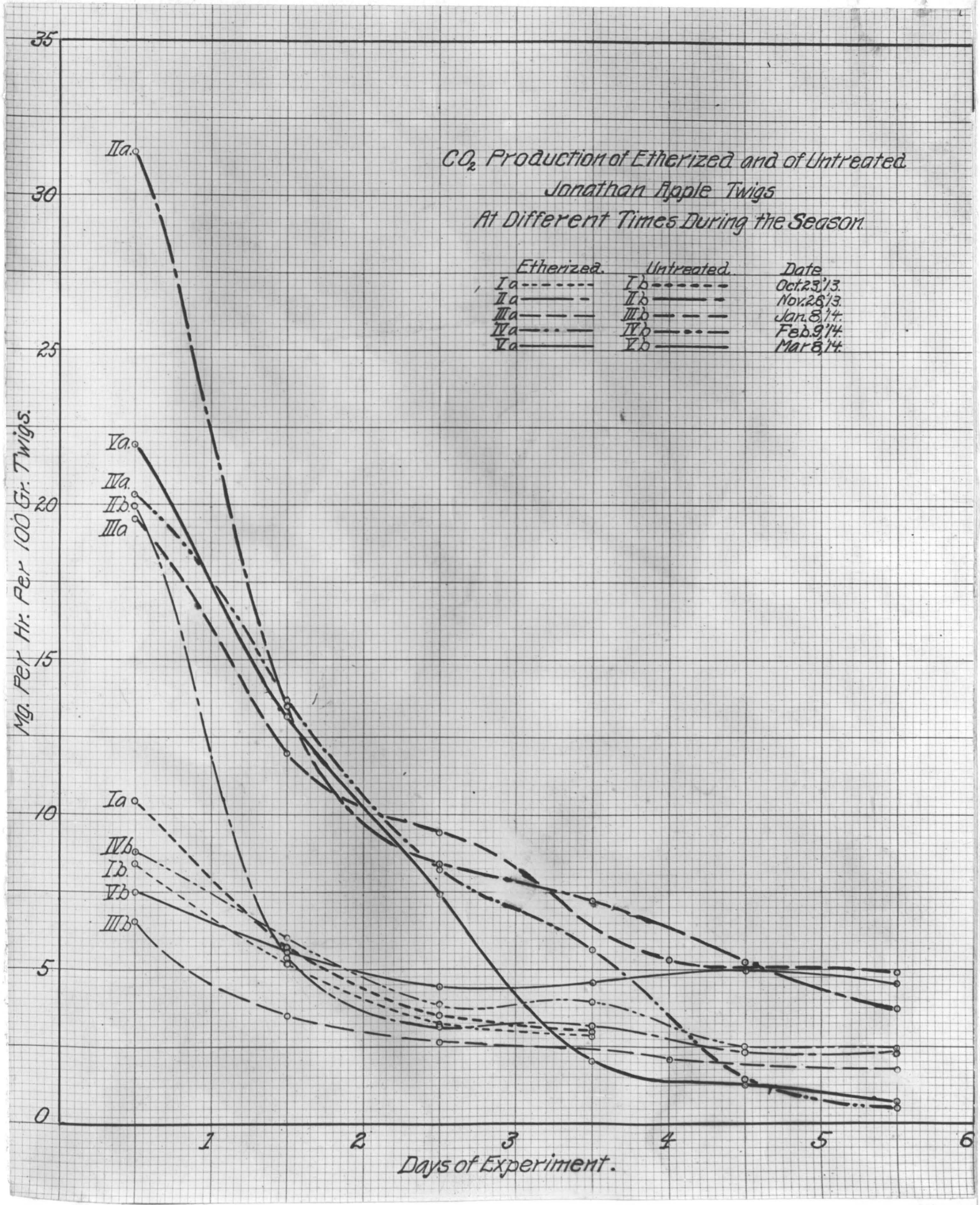



twigs. In all cases, the figures are averages of three samples which represented over $400 \mathrm{gr}$. of materlal. The KOH bulbs were welghed once every twenty-four hours.

The data are showh graphically in the form of curves on plate 6. The $\mathrm{mg}$. of $\mathrm{CO}_{2}$ produced by $100 \mathrm{gr}$. twigs per hour, are laid off on the vertical and the days of the experiment on the horizontal. The points are located half way between the beginnings and the ends of the days, and not at the end of the day when the bulbs were welghed. This is done because the points are averages of twenty-four hours being reduced to the one hour basis from weighings made once a day. The Roman numerals Indicate the number of the experiments. The dates on which these experiments were started are indicated in the right hand corner of the plate. The curves labeled " 4 " show the $\mathrm{CO}_{2}$ production of etherized twigs; those labeled "B", of the untreated material. IA and IB show the curves of $\mathrm{CO}_{2}$ production of the etherized and of untreated twigs respectively during experiment I which was started on oct. 23, 1913. Similarly IIA and IIB, IIIA and IIIB are parallel pairs.

1 glance atplate 5 shows that in all oases the ether1zed material gave off more $\mathrm{CO}_{2}$ during the first few days than the untreated whose $\mathrm{CO}_{2}$ production was determined at the same time, 1.e., IA gave off more than IB; IIA more than IIB, etc. $\Delta$ more detailed examination show that the individual 

etherization curves differ markedly both in their location with respect to the curves of the untreated twigs as well as in the amount of curvature. In experiment $\mathbf{I}, \mathbf{A}$ is but very little above B, and both curves run nearly parallel to each other. In II, $\mathrm{A}$ is considerably above B. In both cases the $\mathrm{CO}_{2}$ production falls off very rapidly during the first two days. So far as known, the experimental conditions were exactiy the same during these days as during the remaining days, and also similar to the conditions under which the other $\mathrm{CO}_{2}$ determinations were made. The decline in $A$ and $B$ became less marked after the second day. The former fell somewhat more than the latter. In III, $A$ is far above B. Curve III B is the lowest of the curves for $\mathrm{CO}_{2}$ production of untreated twigs. This determination was made on January 8 , in the middle of the dormant season when one would expect normal activity to be very low. Curve IVA started out much above its mate, IVB, but it declined fairly uniformly until it actually went below B during the fifth day. This curve departs from the behavior shown by IA, IIA, and IIIA. All these eurves decline much more rapidly during the first day than thereafter, and none of them go below the respective $B$ curves during the time of the experiment. Curve VA behaves somewhat like IVA. It declines even more uniformly, intersecting VB at the end of the third day. Curve vB declines less rapidy during the first day than any other curve. After the third day it is higher than any other B curve. 

This determination was made late in the season. The buds, however, were still docmant, but judging from the behavior of the $\mathrm{CO}_{2}$ production, they had passed their rest period and were held back only by unfarorable weather conditions.

Some of the points to which attention has been directed are brought out more clearly in numerically expressed ratios between the $\mathrm{CO}_{2}$ production of etherized and of untreated material. Such ratios are given in table 8 , page 25. The values were obtained in the manner explained before. The last column of the table gives the arerages of all the ratios.

The data is table 8 are represented graphically by the curves in plate 6 . The ratios in the left hand portion of the plate are laid off in the vertical, and the days of experiment on the horizontal. Roman numerals here as before represent the numbers of the experimentss which were performed on the dates given in the upper part of the plate. The heavy horizontal line 1.00 , represents the amount of $\mathrm{CO}_{2}$ produced by the untreated twigs.

Curve I is only a little above the line for the untreated material. Curve II starts out higher than I. It ascends until it reaches a maximum during the third day after which it begins to decline. Curve III starts out much higher than either I or II. It behaves somewhat like II in that it rises until the third day after which it begins to decline. Curve IV starts out over twice as high as II. It declines from 



\section{Plate 6.}

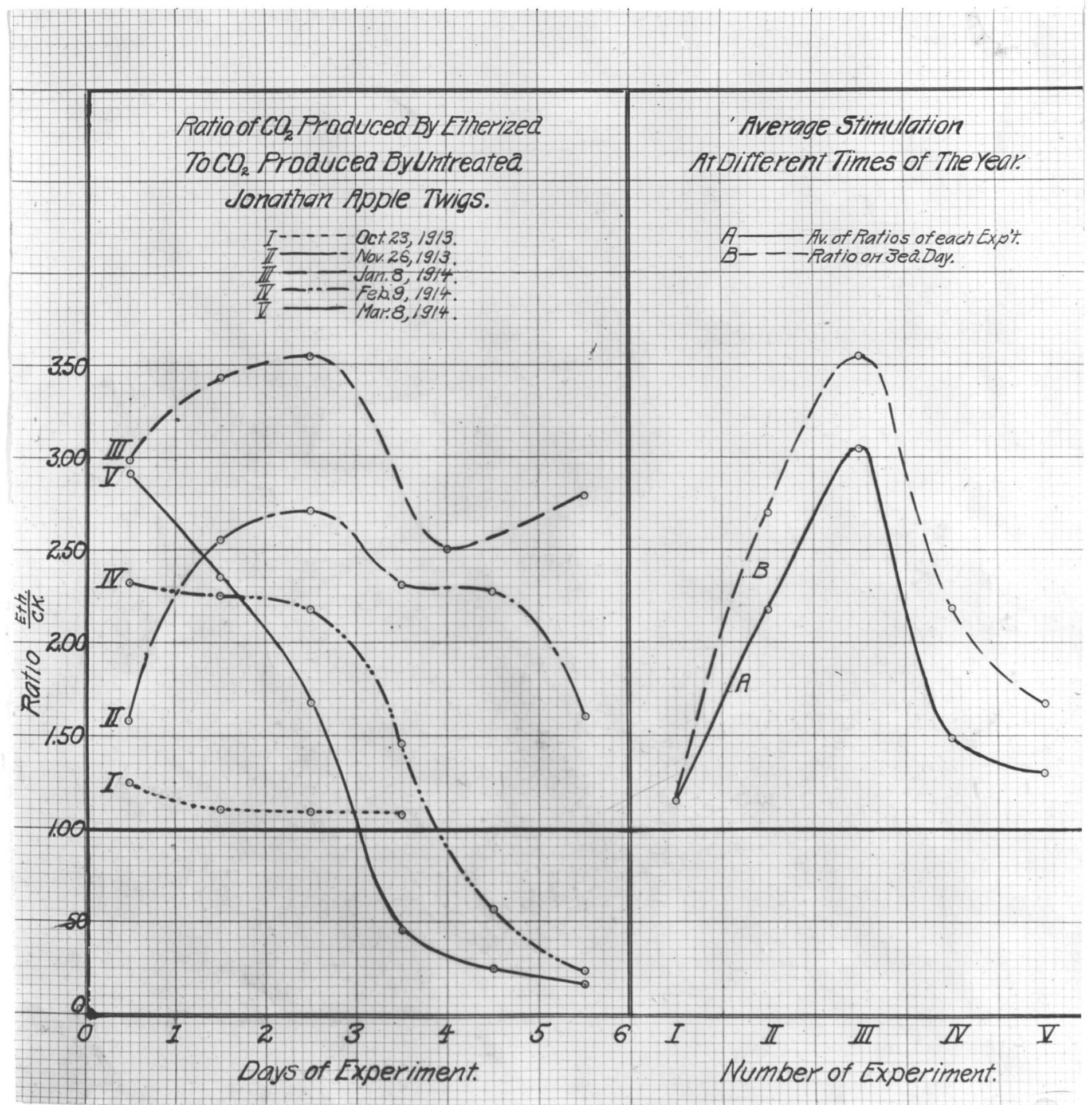



the start, at first slowly then more rapidly. It finally cuts Iine 1.00 during the latter part of the experiment. Curve V starts out rather high but it goos down very rapidy falling below line 1.00 even before IV.

The nearer the close of the dormant season is approached, the shorter the period during which etherized twigs produce more $\mathrm{CO}_{2}$ than unetherized material.

In the right hand portion of plate 6 , the numbers of the experiment are laid off on the horizontal. Since the experiments were performed approximately one month apart, the points also indicate the various dates during the season.

Curve A is obtained by plotting the data in the last column of table 8. This curve again shows that during the early part of the season, etherization exerts relatively little influence toward increasing the $\mathrm{CO}_{2}$ production of dormant twigs. This is shown by the proximity of the point for I to the line 1.00. A month later the effect of ether is much more apparent. About the first of January the maximum stimulation was obtained. After another month, the stimulatory effect of etherization becomes less. It is even less after still another month.

Curve B in which the ratiospbtained on the third day of each experiment are plotted, brings out the same facts. In connection with each experiment etherized and untreated twigs were put in beakers of water and placed in the 

greenhouse where they were allowed to grow. In general, the results obtained were similar to those given by other investigators. During the first part of the season, the twigs grew with difficulty. Etherization did not cause an earlier growth but somewhat later, growth came rather sooner than in untreated material. When the stimulation of $\mathrm{CO}_{2}$ was most marked, the etherized twigs grew very quickly and several weoks ahead of the untreated. In the latter part of the season the etherized specimens came out only a few days ahead of the untreated, and in the last experiment, the untreated twigs outgrew the etherized ones even though the latter opened a day or two before. These forcing results with apple twigs are very similar to those given by Johannsen (53) for bulbs.

The results of these respiration experiments will be discussed in another part of this paper.

\section{B. EXPERIMENTS ON ENZYIE ACTIVITY.}

It is known that the enzymes will become inactive if the products of their work are not utilized in some way or other. (Pfeffer (88) I p.506). As Klebs (57) points out, the leaves of many plants continue to elaborate food in autumn for some time after length growth has ceased. As a result, the assimilated food accumulates so that the work of the ferments is greatly hindered untilthey finally become entirely inactive. As previously stated, Klebs believes that every rest period can be 

broken if it is found possible to arouse the fermentative activity. Do agents which break the rest period have an effect on the enzyme activity of the twigs? The object of the following experiments was to determine just what effect rest-period breaking agents have on these ferments. Material Used:

For the most part, one year old apple twigs were used for these experiments. In a few cases older wood was made use of. The material was taken from vigorous Jonathan, Ben Hur, Ben Davis, Payne's Keeper, Red June and Nixonite apple trees, which were growing in the station orchard at Columbia, Mo. The enzyme activity of Quercus coccinea, Fraxinus Ornus, Forsythia suspensa, and Prunus Persica was also determined. One year twigs were used in all these cases.

The method of collecting the one year twigs and then dividing them into similar lots was the same as described in detail under the respiration experiments. To obtain similar samples of old wood, alternating sections of the same branch were used for treated and for untreated material, respectively. When the enzyme activity of buds alone was to be tested, large branches containing an abundance of spurs were collected. These were then cut into smaller parts. Similar parts growing adjacent to each other were divided into lots to be treated and lots which were to remain untreated, respectively.

The agents emplojed to break the rest period were 

otherization, drying, warm water bath, alcohol bath, hydrochloric acid bath, sodium nitrate spray, and mechanical injury. The strength as well as the duration of the treatments are given in the tables. "I Ether" means that the standard dose of $0.5 \mathrm{cc}$ per litre was used; "2 Ether" and" $\frac{1}{8}$ Ether" mean that 1. cc and $0.25 \mathrm{cc}$ per litre respectively were used. Btherization was carried out as previously described.

Suitable checks were used in all cases; e.g., if the treated twigs were belng bathed in alcohol, the untreated or check twigs were immersed in pure water during the same period. This was done to equalize as far as possible the effect that exclusion of free oxygen from the twigs might have on the enzyme activity of the tissue. Similar precautions were taken in case of checks for other forms of treatment.

The enzyme activity was determined either immediately after the close of the period of application of the stimulant or after an interval of one or more days. During this interval the twigs were kept standing at room temperatures in beakers containIng about 50 cc. of tap water.

Preparation of the Naterial for the Pnzyme Test:

The outer fleshy parts only were used to determine the enzyme activity of the twigs. This fleshy portion, including the cortex proper, the bast layer, the cambium and more or less of the sap wood as well as the lateral and terminal buds have been called "cortex" in the table for the sake of convenience. The term is 

used very loosely. The buds alone would be most desirable for enzymatic tests. However, it is difficult to obtain an abundance of material of this kind. The hard, woody part of the twig is very inactive enzymatically. Hence the choice of the fleshy portions.

This "cortex" was scraped from the twigs with a knife. The shavings thus secured were then finely ground in a "Keen Kutter" meat and food chopper. Such a chopper can be obtained from almost any hardware dealer. The chopper shears the tissue into fine particles but does not squeeze out the juice, if the material is not too succulent. The ground up mass of cortex was very uniform throughout.

When buds only were used to determine the enzyme activity, the entire buds together with about $3-5 \mathrm{~cm}$. of the spur on which they grew were ground up.

Several $5 \mathrm{gr}$. samples of each kind of material were carefully weighed out and placed in glass vials. 1. Diastatic Activity:

The determination of diastatic activity was carried out in the following manner. After the material had been prepared as described above, $25 \mathrm{cc}$. of a 2 per cent potato starch paste were added to each vial. The starch paste was made by adding $90 \mathrm{cc}$. of boiling water to $2 \mathrm{gr}$. c.p. potato starch which had been wet by $10 \mathrm{cc}$. cold water. After cooling 2 per cent toluene was adced to this paste. 

The amount of starch solution added to the vial was just sufficient to cover the $5 \mathrm{gr}$. of cortex material, so that all material had a chance to act, and all starch was exposed to action by the ferments. As soon as the starch was added and mixed with the mass of "cortex" material, the vials were put in in incubatot at a temperature of $35^{\circ} \mathrm{C}$.

At intervals of one or two hours, the material in each vial was again thoroughly mixed by means of a clean glasa rod. After this, $\frac{1}{2}$ or 1 cc. of the liquid from each sample was remored by means of pipettes and placed in a number of syracuse watch glasses. There were two watch glasses for each sample. These watch glasses, which have flat bottoms, were placed on a white surface near a good natural 11ght. A few arops of iodine solution were added to the liquid in each glass. Whenever the color produced by the addition of the iodine faded out, more lodine was added until a permanent color was obtained. Care had to be taken not to add too much iodine which would obscure the color.

The characteristic blue color obtained by ading the lodine to starch is familiar to all. If starch has been subjected to the action of a starch-changing ferment - diastase - for a time, then the addition of lodine no longer gives a blue but a blue-purple or violet, red-purple, red, red-brown, yellow-brown or no color at all. The particular color obtained depends upon the amount of enzyme which is acting and upon the time it is allowed 

to act if temperature and other factors are constant. If a given amount of ferment acts on starch for a short time, then a bluepurple color is obtained by adding lodine; if it acts for a very long time, we finelly get no color reaction. If a very small amount of enzyme acts on starch for a given time, we may obtain a blue-purple reaction with lodine at the end of that time. A much larger quantity of ferment acting on the same amount of starch for the same time may give a red-brown reaction. Since the color obtained with iodine indicates the degree to which starch has been changed, (Green 36) and since the enzyme is responsible for the change, then the color obtained at the end of a definite time serves as a basis for estimating the enzyme activity. In these experiments the colors obtained at each trial were carefully recorded. All determinations were made in duplicate except in a few cases where the material was too scarce. In practically every case the duplicates showed the same reaction.

It should be mentioned at this time that all observations made by the author were corroborated by the judgements of two or three persons who knew nothing about the details of the experiment. Acknowledgements should be made to all who so willingly gavetheir attention and especially to Miss $\mathrm{K}$. Bailey ana Mr. C. C. Wiggans whose frank juägements were especially valuable in this connection.

To make our results comparative, seven easily recognized colors have been taken as a standard. Water color repro- 

ductions of these are shown on plate 7 , in the order in which they may be obtained. Each color has been numbered beginning with 1 and ending with 7. These numbers are used in the tables. The smaller the number, the less the enzyme activity; the greater the number, the more active the ferments.

That the changes occurring in the experiments were due to enzymes contained in the tissue was taken for granted from the fact that whenever the tissue was heated to $100^{\circ} \mathrm{C}$. for a few minutes and then allowed to act on starch paste, no change occurred. The reaction with iodine was the characteristic blue throughout the time of the experiment. The rapid conversion of the starch (Bayliss 9) and the fact that toluene had been added to prevent organisms from developing, eliminates bacterial activity as being responsible for the changes noted when unheated material was allowed to act.

This method of determining the comparative enzyme activity is of course not free from objections. A probable source of error is found in the fact that many substances are dissolved from the tissue in adition to the enzymes. Some of these substances e.g. tannin may hinder to some extent the free action of the enzymes. However, it is likely that the same amount of these inhibiting factors are present in both check and treated material, so that the comparative value of the results remain unaffected. Again the results are not as quantitative as might be desirbd. On the whole, however, the methods outlined have given 



\section{Plate?}

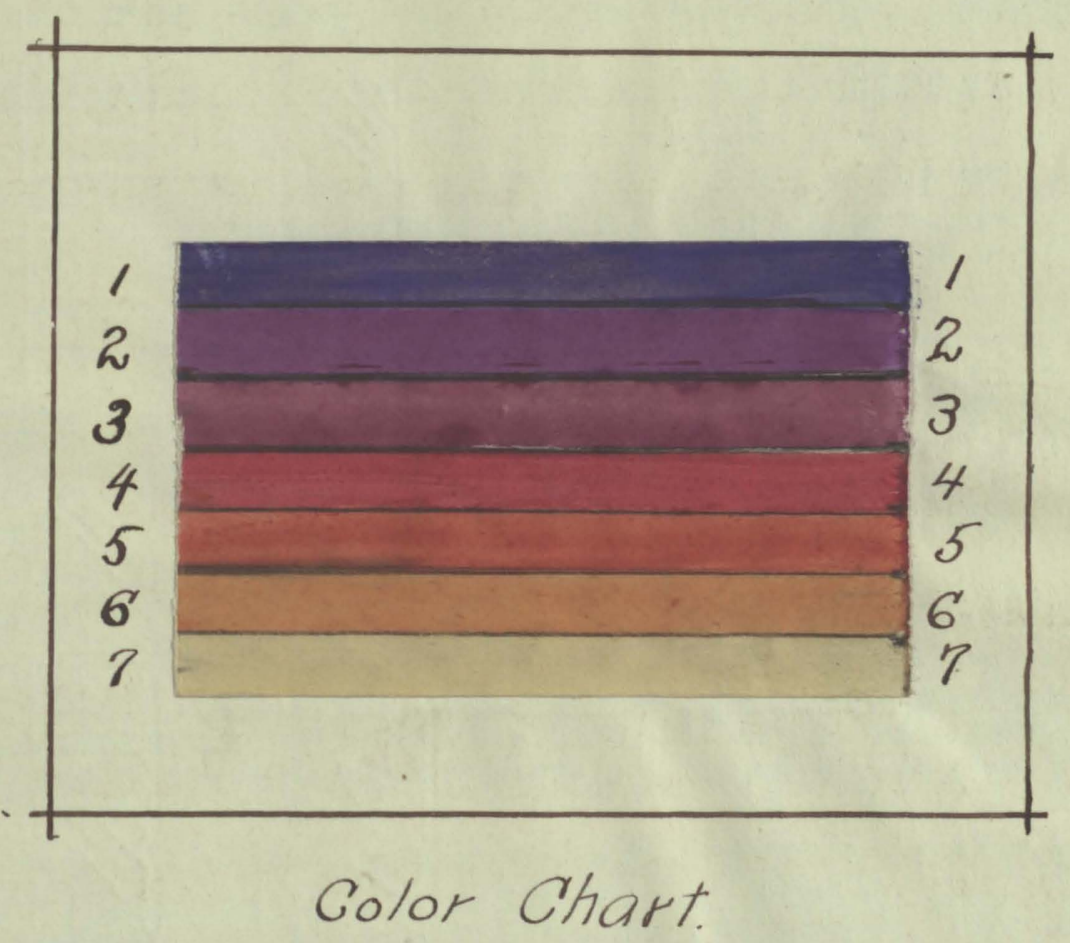

(see Text) 

very satisfactory results for these preliminary experiments. The simplicity of the tests and the reliability of the results are points in favor of the method.

The results obtained with the diastatic enzyme experiments are summarized in tables 9 to 13. In all cases, the dates show when the material was collected. Fnzyne activity was determined after two and after four hours. This activity is expressed in numbers which are based on color reactions as previously explained. It should be kept in mind that the greater the number, the greater the enzyme activity. The plus sign after the numbers indicates that the color is close to the next more advanced; the minus sign indicates that the color barely passed the less advanced. For example, 2 - and $2+$ indicate that both give blue-purple reaction with lodine; 2- however, has little purple and much blue, while $2+$ is almost but not quite, red-purple. The abbreviations "Untr." and "Tr." stand for untreated andtreated, respectively. The other terms in the table are self explanatory.

The data in table 9, page 38, show that the agents which are known to break the rest period, also increase the diastatic enzyme activity of dormant tissue. In every case, the numbers in the column headed "treated" are greater than those in the column for "untreated." The amount of increase obtained varies in different cases depending upon the agent used, the species, variety and other factors. It should not be supposed that stimulation is obtained in all cases. Instances in which 

Table No. 9

Stinulation of Diastatio Enzyme Activity of Dormant Pyrus malus Twigs Due to Agents Which Break the Rest Period.

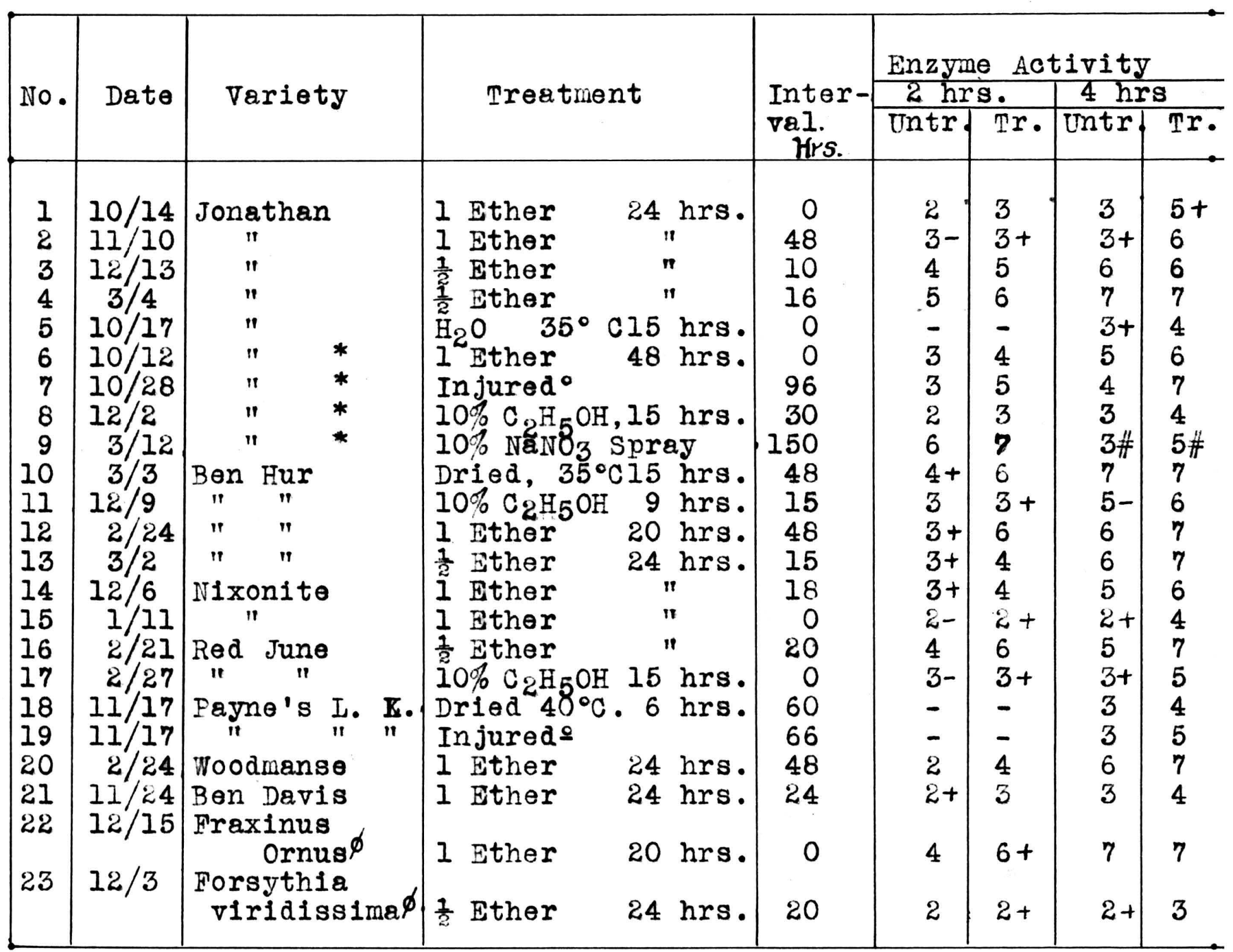

* Buds only used to determine enzyme activity.

- Injured by piercing buds with needle.

-Injured by pounding internodes with knife handle. \#After $1 \mathrm{hr}$.

фspecies. 

the rest-period-breaking agents have either no effect or even an inhibitory influence will be given in the tables which follow.

The date of application of the agent is an important factor in the enzyme determinations, as may be seen from the data in table 10, page 40. In some cases the enzymes apparently are not stimulated in the early part of the season; but the samo treatment applied a few months later will cause increased enzyme aotivity. (Cf. 5). In other cases, a dose of ether might prove effective early in the season, while later on, it has very little. or no effect whatever. (Cf. 3 and 4). In still other cases the late treatment actually causes. the enzymes in the tissue to become less active than those in untreated material. (Cf. 1, 4 and 6). Attention should be called to the fact that in practically all cases, the enzyme activity of the untreated twigs increases as the season advances.

The enzymes in the oak do not seem to be affected by the particular treatment given them.

The influences of the intensity of the treatment on the enzyme activity of the twigs is shown in table 11, page 41. The data indicate that in most cases, a weak dose of a given stimulant increases the fermentative action when the stronger dose has no influence or even causes a diminished activity. Unfortunately, most of these experiments were carried out late in the season. It is very probable that during the early season, a strong dose might have increased the enzyme work when a weaker dose would have 

Table No. 10

Diastatic Enzyme Activity of Dormant Pyrus malus Twigs as Influenoed by same Treatment at Different Times of the season.

\begin{tabular}{|c|c|c|c|c|c|c|c|c|c|}
\hline \multirow{3}{*}{$\frac{\text { No. }}{1}$} & \multirow{3}{*}{$\begin{array}{c}\text { Variety } \\
\text { Jonathan }\end{array}$} & \multirow{2}{*}{\multicolumn{2}{|c|}{ Treatment }} & \multirow{3}{*}{$\begin{array}{c}\text { Inter- } \\
\text { val Hrs. }\end{array}$} & \multirow{3}{*}{$\begin{array}{r}\text { Date } \\
10 / 14 \\
11 / 10 \\
3 / 13\end{array}$} & \multicolumn{4}{|c|}{ Enzyme Activity } \\
\hline & & & & & & \multicolumn{2}{|c|}{$2 \mathrm{hrs}$. } & \multicolumn{2}{|c|}{4 hrs. } \\
\hline & & & & & & & & & \\
\hline & & I Ether & $24 \mathrm{hrs}$. & & & $\begin{array}{l}2 \\
3- \\
5\end{array}$ & $\begin{array}{l}3 \\
2+ \\
4-\end{array}$ & $\begin{array}{l}3 \\
5 \\
7\end{array}$ & $\begin{array}{l}5 \\
3 \\
7\end{array}$ \\
\hline 2 & * * & In jured ${ }^{\circ}$ & & 96 & $\begin{array}{r}11 / 28 \\
3 / 11\end{array}$ & $\begin{array}{l}3 \\
4\end{array}$ & $\begin{array}{l}5 \\
4+\end{array}$ & $\begin{array}{l}4 \\
7\end{array}$ & $\begin{array}{l}7 \\
7\end{array}$ \\
\hline 3 & Nixonite & I Ether & $24 \mathrm{hrs}$. & 0 & $\begin{array}{l}1 / 11 \\
3 / 12\end{array}$ & $\begin{array}{l}2- \\
3+\end{array}$ & $\begin{array}{l}2+ \\
3+\end{array}$ & $\begin{array}{l}2+ \\
7\end{array}$ & $\begin{array}{l}4 \\
7\end{array}$ \\
\hline 4 & Ben Davis & 1 Ether & $n$ & 20 & $\begin{array}{c}11 / 24 \\
3 / 9\end{array}$ & $\overline{3}$ & $\overline{2}$ & $\begin{array}{l}3 \\
4\end{array}$ & $\begin{array}{l}4- \\
2\end{array}$ \\
\hline 5 & Ben Hur & $\frac{1}{2}$ Ether & $"$ & 18 & $\begin{array}{c}12 / 10 \\
3 / 2\end{array}$ & $\begin{array}{l}3+ \\
3+\end{array}$ & $\begin{array}{l}3+ \\
4-\end{array}$ & $\begin{array}{l}4 \\
6\end{array}$ & $\begin{array}{l}4 \\
7\end{array}$ \\
\hline 6 & $\begin{array}{l}\text { Fraxinus } \\
\text { Ornus } \phi\end{array}$ & 1 Ether & $20 \mathrm{hrs}$. & 0 & $\begin{array}{r}12 / 15 \\
3 / 18\end{array}$ & $\begin{array}{l}4 \\
6 \#\end{array}$ & $\begin{array}{l}6+ \\
4 \#\end{array}$ & ? & $\begin{array}{l}7 \\
-\end{array}$ \\
\hline$\eta$ & $\begin{array}{l}\text { Quercus } \\
\text { coccinea }\end{array}$ & 1 Ether & $24 \mathrm{hrs}$. & 0 & $\begin{array}{r}12 / 21 \\
3 / 12\end{array}$ & $\begin{array}{l}2 \\
2\end{array}$ & $\begin{array}{l}2 \\
2-\end{array}$ & $\begin{array}{l}2+ \\
2+\end{array}$ & $\begin{array}{l}2+ \\
2+\end{array}$ \\
\hline
\end{tabular}

*Buds only used to determine Enzyme Activity.

- Injured by piercing buds.

\#After $1 \mathrm{hr}$.

$\phi$ Species. 

Table No. 11

Diastatic Enzyme Activity of Dormant Pyrus malus Twigs as Influenced by Different Intensities of the same rreatment.

\begin{tabular}{|c|c|c|c|c|c|c|c|c|c|}
\hline \multirow{3}{*}{ No. } & \multirow{3}{*}{ Date } & \multirow{3}{*}{ Variety } & \multirow{3}{*}{\multicolumn{2}{|c|}{ Treatment }} & \multirow{3}{*}{$\begin{array}{l}\text { Inter- } \\
\text { val } \\
\text { Hrs. }\end{array}$} & \multicolumn{4}{|c|}{ Enzyme Activity } \\
\hline & & & & & & \multicolumn{2}{|c|}{$2 \mathrm{hrs}$. } & \multicolumn{2}{|c|}{4 hrs. } \\
\hline & & & & & & Untr & $\mathrm{Tr}$ & Untr & Tr. \\
\hline 1 & $12 / 6$ & Nixonite & $\begin{array}{l}1 \text { Ether } \\
2 \text { Ether }\end{array}$ & $24 \mathrm{hrs}$ & $\begin{array}{l}18 \\
18\end{array}$ & $\begin{array}{l}3+ \\
3+\end{array}$ & $\begin{array}{l}4 \\
3-\end{array}$ & $\begin{array}{l}5 \\
5\end{array}$ & $\begin{array}{l}6 \\
3+\end{array}$ \\
\hline 2 & $12 / 13$ & Jonathan & $\begin{array}{l}\frac{1}{1} \text { Ether } \\
\frac{2}{2} \text { Ether }\end{array}$ & $"$ & $\begin{array}{l}10 \\
10\end{array}$ & $\begin{array}{l}4 \\
4\end{array}$ & $\begin{array}{l}4- \\
5\end{array}$ & $\begin{array}{l}6 \\
6\end{array}$ & $\begin{array}{l}5 \\
6+\end{array}$ \\
\hline 3 & $2 / 21$ & Woodmanse & $\begin{array}{l}\frac{1}{2} \text { Ether } \\
\frac{1}{2} \text { Ether }\end{array}$ & $"$ & $\begin{array}{l}20 \\
20\end{array}$ & $\begin{array}{l}5+ \\
5+\end{array}$ & $\begin{array}{l}3+ \\
6\end{array}$ & $\begin{array}{l}6 \\
6\end{array}$ & $\begin{array}{l}5- \\
6+\end{array}$ \\
\hline 4 & $2 / 21$ & Red June & $\begin{array}{l}\frac{1}{1} \text { Ether } \\
\frac{1}{2} \text { Ether }\end{array}$ & " & $\begin{array}{l}20 \\
20\end{array}$ & $\begin{array}{l}4 \\
4\end{array}$ & $\begin{array}{l}3+ \\
6\end{array}$ & $\begin{array}{l}5 \\
5\end{array}$ & $\begin{array}{l}6 \\
7\end{array}$ \\
\hline 5 & $2 / 21$ & Payne's L. K. & $\begin{array}{ll}\frac{1}{1} & \text { Ether } \\
\frac{1}{2} & \text { Ether }\end{array}$ & " & $\begin{array}{l}20 \\
20\end{array}$ & $5-$ & $\begin{array}{l}2 \\
3\end{array}$ & $\begin{array}{l}6 \\
6\end{array}$ & $\begin{array}{l}3 \\
4\end{array}$ \\
\hline 6 & $3 / 2$ & Ben Hur & $\begin{array}{l}\frac{1}{1} \text { Ether } \\
\frac{1}{2} \text { Ether }\end{array}$ & " & $\begin{array}{l}15 \\
15\end{array}$ & $\begin{array}{l}3+ \\
3+\end{array}$ & $\begin{array}{l}3- \\
4-\end{array}$ & $\begin{array}{l}6+ \\
6+\end{array}$ & $\begin{array}{l}6- \\
7\end{array}$ \\
\hline 7 & $3 / 4$ & Jonathan & $\begin{array}{l}\text { I Ether } \\
\frac{1}{2} \text { Ether }\end{array}$ & $"$ & $\begin{array}{l}16 \\
16\end{array}$ & $\begin{array}{l}5 \\
5\end{array}$ & $\begin{array}{l}3 \\
6\end{array}$ & $\begin{array}{l}7 \\
7\end{array}$ & $\begin{array}{l}6+ \\
7\end{array}$ \\
\hline 8 & $3 / 2$ & King David & $\begin{array}{l}1 \text { Ether } \\
\frac{1}{2} \text { Ether }\end{array}$ & " & $\begin{array}{l}15 \\
15\end{array}$ & $\begin{array}{l}3+ \\
3+\end{array}$ & $\begin{array}{l}2 \\
3\end{array}$ & $\begin{array}{l}6 \\
6\end{array}$ & $\begin{array}{l}4 \\
5\end{array}$ \\
\hline 9 & $2 / 27$ & Red June & $\begin{array}{l}10 \% \\
20 \% \\
\mathrm{C}_{2}\end{array}$ & $15 \mathrm{hrs}$. & $\begin{array}{l}0 \\
0\end{array}$ & $\begin{array}{l}3- \\
3-\end{array}$ & $\begin{array}{l}3+ \\
3-\end{array}$ & $\begin{array}{l}3+ \\
3+\end{array}$ & $\begin{array}{l}5 \\
3+\end{array}$ \\
\hline 10 & $12 / 9$ & Ben Hur & $\begin{array}{l}\text { Dried } 35^{\circ} \\
\text { Dried } 35^{\circ}\end{array}$ & C. ${ }^{7} \mathrm{hrs}^{\mathrm{hrs}}$ & $\begin{array}{r}17 \\
6\end{array}$ & $\begin{array}{l}3 \\
3\end{array}$ & $\begin{array}{l}3 \\
2+\end{array}$ & $\begin{array}{l}5 \\
5\end{array}$ & $\begin{array}{l}5 \\
3\end{array}$ \\
\hline 11 & $12 / 10$ & Ben Hur & $\begin{array}{ll}\mathrm{H}_{2} \mathrm{O} & 35^{\circ} \\
\mathrm{H}_{2} \mathrm{O} & 35^{\circ} \\
\mathrm{H}_{2} \mathrm{O} & 35^{\circ}\end{array}$ & $\begin{array}{lc}3 & \text { hrs. } \\
6 & " \\
9 & "\end{array}$ & $\begin{array}{l}19 \\
16 \\
13\end{array}$ & $\begin{array}{l}2+ \\
2+ \\
2+\end{array}$ & $\begin{array}{l}2+ \\
2+ \\
2+\end{array}$ & $\begin{array}{l}3- \\
3- \\
3-\end{array}$ & $\begin{array}{l}4^{-} \\
4+ \\
5\end{array}$ \\
\hline
\end{tabular}



no effect.

This table shows very nicely how different varieties of apples behave in respect to their enzyme activity under similar treatment.

Another factor which influences the enzyme activity is the intervals after treatment as shown in table 12, page 43 . In most cases the treated material shows a greater activity after an interval; than it does immediately after treatment. (Cf. 1 , $2,3,4,5,8)$. In some cases an interval may bring about. less enzyme activity than immodiately after treatment even though the ferments are still more active than those in untreated twigs. The interval seems to be unfavorable for the enzyme activity of the untreated material. (Cf. $1,3,4,5,6)$. In a few cases a rather long interval seems to bring about an increase in the fermentative activity, though an excessively long interval again diminishes the rapiaity of the enzyme action of untreated material. (CI. 7 and 8).

Table 13 has been inserted in order to show how the enzyme activity of different tissues of Pyrus malus vary with and without treatrent. Cortex, as previously explained, refers to all fleshy parts of the twig including lateral and terminal buds. "Twigs minus cortex" is what remains after renoving the fleshy parts. The other terms used in the table are self-explanatory. As might be expected the different tissues vary as far as their enzyme activity is concerned. The older the cortex 

Table No. 12

Diastatic Enzyme Activity of Dormant Pyrus malus Twigs as Influenced by the Interval after Treatment.

\begin{tabular}{|c|c|c|c|c|c|c|c|c|c|c|}
\hline \multirow{3}{*}{ No. } & \multirow{3}{*}{$\begin{array}{c}\text { Date } \\
10 / 26\end{array}$} & \multirow{3}{*}{\begin{tabular}{|l} 
Variety \\
Jonathan
\end{tabular}} & \multirow{2}{*}{\multicolumn{3}{|c|}{ Treatment }} & \multirow{3}{*}{$\begin{array}{c}\text { Interva] } \\
\text { Hrs. } \\
0 \\
14\end{array}$} & \multicolumn{4}{|c|}{ Enzyme Activity } \\
\hline & & & & & & & \multicolumn{2}{|c|}{$\begin{array}{c}2 \text { hrs. } \\
\text { Untr }\end{array}$} & \begin{tabular}{|l|}
$4 \mathrm{~h}$ \\
Untr \\
\end{tabular} & Irs. \\
\hline & & & & Ether & $24 \mathrm{hrs}$. & & $\begin{array}{l}3 \\
2\end{array}$ & $\begin{array}{l}3- \\
5\end{array}$ & $\begin{array}{l}3+ \\
3+\end{array}$ & $\begin{array}{l}3 \\
7\end{array}$ \\
\hline 2 & $11 / 10$ & $"$ & & Ether & $"$ & $\begin{array}{r}0 \\
48\end{array}$ & $\begin{array}{l}3- \\
3-\end{array}$ & $\begin{array}{l}2+ \\
3+\end{array}$ & $\begin{array}{l}5 \\
4\end{array}$ & $\begin{array}{l}8 \\
6\end{array}$ \\
\hline 3 & $3 / 13$ & $n$ & 1 & Ether & $n$ & $\begin{array}{r}0 \\
48\end{array}$ & $\begin{array}{l}5 \\
4\end{array}$ & $\begin{array}{l}4 \\
6^{+}\end{array}$ & $\begin{array}{l}7 \\
7\end{array}$ & $\begin{array}{l}7 \\
7\end{array}$ \\
\hline 4 & $2 / 24$ & Ben Hur & & Ether & $20 \mathrm{hrs}$. & $\begin{array}{r}0 \\
48\end{array}$ & $\begin{array}{l}4 \\
3\end{array}$ & $\begin{array}{l}3+ \\
6\end{array}$ & $\begin{array}{l}6+ \\
6\end{array}$ & $\begin{array}{l}6 \\
7\end{array}$ \\
\hline 5 & $2 / 24$ & Woodmanse & 1 & Ether & $n$ & $\begin{array}{r}0 \\
48\end{array}$ & $\begin{array}{l}4+ \\
3\end{array}$ & $\stackrel{5}{6}$ & $\begin{array}{l}7 \\
6\end{array}$ & $\begin{array}{l}7 \\
7\end{array}$ \\
\hline 6 & $3 / 13$ & Nixonite & & Ether & 24 hrs. & $\begin{array}{r}0 \\
28\end{array}$ & $\begin{array}{l}3+ \\
3\end{array}$ & $\begin{array}{l}3+ \\
4+\end{array}$ & $\begin{array}{l}7 \\
7\end{array}$ & $\begin{array}{l}7 \\
7\end{array}$ \\
\hline 7 & $3 / 2$ & Ben Hur & & Ether & $"$ & $\begin{array}{r}15 \\
96 \\
200\end{array}$ & $\begin{array}{l}3+ \\
5 \\
3+\end{array}$ & $\begin{array}{l}3- \\
7 \\
4+\end{array}$ & $\begin{array}{l}7 \\
6+ \\
7\end{array}$ & $\begin{array}{l}7 \\
\overline{6}-\end{array}$ \\
\hline 8 & $3 / 2$ & King David & & Ether & $"$ & $\begin{array}{r}15 \\
96 \\
200\end{array}$ & $\begin{array}{l}3+ \\
4 \\
3+\end{array}$ & $\begin{array}{l}2 \\
3- \\
4+\end{array}$ & $\begin{array}{l}6 \\
6 \\
7\end{array}$ & $\begin{array}{l}4 \\
5 \\
6-\end{array}$ \\
\hline
\end{tabular}



Table No. 13

Diastatic Enzyme Activity of Different Tissues of Pyrus malus. Treated vs. Untreated.

\begin{tabular}{|c|c|c|c|c|c|c|c|c|}
\hline \multirow{3}{*}{ No. } & \multirow{3}{*}{ Date } & \multirow{3}{*}{ Treatment } & \multirow{3}{*}{$\mid \begin{array}{l}\text { Inter- } \\
\text { val Hrs. }\end{array}$} & \multirow{3}{*}{ Tissue } & \multicolumn{4}{|c|}{ Enzyme Activity } \\
\hline & & & & & \multicolumn{2}{|c|}{ 2hrs. } & \multicolumn{2}{|c|}{$4 \mathrm{hrs}$. } \\
\hline & & & & & Untr. & Tr. & Untr. & Tr. \\
\hline & & & & Buds on spurs & 4 & 6 & 7 & 7 \\
\hline 1 & $3 / 12$ & 1 Ether 24 hrs. & 0 & $\begin{array}{c}\text { twigs } \\
\text { Cortex of }\end{array}$ & 2 & 2 & 5 & 5 \\
\hline & & & & twiggs & 5 & 4 & 7 & 7 \\
\hline 2 & $3 / 12$ & 1 Ether $24 \mathrm{hrs}$. & 16 & $\begin{array}{l}\text { Entire twigs } \\
\text { I yr. old } \\
\text { Twig minus cortex } \\
\text { Cortex } 1 \text { yr. old }\end{array}$ & $\begin{array}{l}3^{-} \\
2^{+} \\
3^{+}\end{array}$ & $\begin{array}{l}2 \\
2- \\
4\end{array}$ & $\begin{array}{l}6 \\
4- \\
6\end{array}$ & $\begin{array}{l}5 \\
3 \\
7\end{array}$ \\
\hline 3 & 721 & & & Buds & $2+$ & 3 & 3 & 4 \\
\hline & 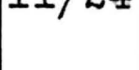 & & 24 & $\begin{array}{c}\text { twigs } \\
\text { twi }\end{array}$ & $2-$ & 2 & $2+$ & 3 \\
\hline
\end{tabular}

No. 1 Jonathan

" 2 King David

" 3 Ben Davis 

was least active at the latter part of the season. (Cf. 1). The same tissues were tested for their enzyme activity during october. Unfortunately at that time the plan of recording the enzyme activity had not yet been adopted and therefore the results are not included in the table. The observations recorded in the notes are as follows: Untreated material showed a little more action than etherized; bud material showed least; - 1 year cortex medium; older cortex most enzyme activity. This is the reverse of what obtains in the late season.

The reasons for choosing the cortex for most of the enzyme determinations have been mentioned. The above table gives experimental evidence which indicates that the one year cortex is rather active as compared with older cortex, with the entire twig, or with the hard woody parts of the twig.

2. Proteolytic Enzymes.

A few experiments have been carried out to determine the effect of rest period-breaking agents upon proteolytic ferments of twig tissue. The methods used were very crude. The results obtained, however, are of sufficient interest to be included in this preliminary discussion, but it should be borne in mind that only a few determinations have been made.

These experiments were carried out as follows: gelatin solution was prepared by adding $20 \mathrm{gr}$. pure gelatin to $100 \mathrm{cc}$. luke-warm water. Each of a number of similar vials received $25 \mathrm{cc}$. of this solution. After the gelatin had harden- 

ed a set of material for the experiment was prepared as follows: In one vial was placed $5 \mathrm{gr}$. of treated apple cortex; in another, $5 \mathrm{gr}$. of untreated cortex; in another, $5 \mathrm{gr}$. treated cortex that had been heated to $100^{\circ} \mathrm{C}$, and in another $5 \mathrm{gr}$. untreated cortex which had been heated to $100^{\circ} \mathrm{C}$. Next $25 \mathrm{cc}$. of pure water sufficient to cover the cortex material - was added to each vial. Also the same quantity of water was added to some vials which contained gelatin but no cortex material. Toluene was added in all cases to prevent bacterial activity. The series was run in duplicate. The material was allowed to act for twenty-four hours at $20^{\circ} \mathrm{C}$.

The amount of solidified gelatin remaining at the end of the period was used as an index to the proteolytic enzyme activity. (Fermi 33).

The results of the test showed very clearly that the ether treatment increased the proteolytic enzyme activity as the least amount of the solid gelatin remained in the vials which contained the unheated cortex from etherized twigs. Very little of the gelatin had liquified in the vials containing water but no cortex.

The experiments were varied by allowing the cortex material to act on one $\mathrm{cm}$. cubes of gelatin. Again, the etherized material showed most action.

3. Fat Splitting Ferments.

A series of experiments were carried out to deter- 

mine whether the fat splitting enzymes of the twig tissue were Influenced by agents which break the rest period. The results of these experiments are not given as being conclusive evidence since too few experiments were made.

The material used for these determinations was cortex from apple and ash twigs. A series of vials were prepared as follows:

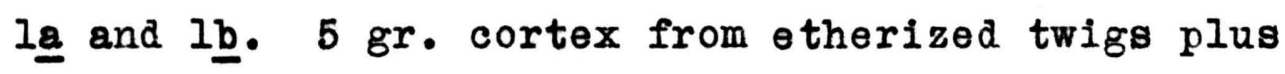
25 cc. castor oil emulsion.

2aand 2b. $5 \mathrm{gr}$. cortex from untreated twigs plus 25 cc. castor oil emulsion.

3a and 3ㅁ. $5 \mathrm{gr}$. heated cortex from otherized twigs plus $25 \mathrm{cc}$. castor oil emulsion.

4a and 4ㅁ. $5 \mathrm{gr}$. heated cortex from untreated twigs plus castor oil emulsion.

5a and 5b $25 \mathrm{cc}$. castor oil emulsion only. One cc. of toluene was added to all vials. The material was allowed to act at $35^{\circ} \mathrm{C}$. for from ten to twenty-four hours. At intervals, some of the liquid in each vial was removed and tested for acidity by adding neutral litmus. In other cases, a few drops of phenolthaline were added to some of the liquid from each vial and then, drop by arop, weak NaOH was also added until the red color appeared. The material requiring the largest amount of $\mathrm{NaOH}, 1 . \theta .$, that which produced most acid, was considered to be most active so far as fat splitting enzymes were 

concerned.

In all cases tried, the etherized material was most active in producing fatty acids. The ash material was more active than the apple. 4. Oxidizing Enzymes.

The work of the oxidizing enzymes as influenced by the rest period-breaking agents was observed throughout the season. The $\mathrm{CO}_{2}$ determinations, to a large extent at least, express the activity of the oxidases. However, the work of these ferments can be detected in other relatively simple ways. The browning of the exposed flesh of apples is familiar to every one. This browning is due to an oxidase (maloxidase). Kastle (54, p.89) has demonstrated that the browning of freshly cut vegetable as tissue which is exposed to air, is due to oxidases in the case of the fruit. The following experiment shows more specifically what may be expected in case of cortex material, and it also demonstrates the reliability of using this color change as a basis for judging the activity of oxidizing enzymes.

On Feb. 8, 1914, some Wolf River apple twigs were collected. The cortex was scraped from these twigs and ground up finely. After mixing this material, a number of $5 \mathrm{gr}$. samples were weighed out, and treated in the following manner:

(A). 2 lots in the open air without further treatment. (B). 2 lots in an atmosphere of ether. (lec. per L.) (C). 2 lots heated to $100^{\circ} \mathrm{C}$., then placed in open air. 

(D). 2 lots heated to $100^{\circ} \mathrm{C}$. then placed in ether atmosphere.

At the end of one hour, all lots were removed to the open air. Iots were somewhat brown. Lots B were very dark brown. Lots $C$ and $D$ were a similar green, showing no change in color whatever. From this it must be concluded that the brown color was produced by stomething in the tissue. Heating prevents the production of the color, and etherization favors it in unheated material. So far as known, the oxidizing ferments are the responsible agents.

In determining how the agents used to break the rest period influenced the oxidases, the cortex was scraped from the treated twigs, ground up and exposed to the air for a short time. The color changes were then noted.

It is difficult to express quantitatively and accurateIy the variations in the shades of brown which have been observed. Hence the results of these preliminary observations are not given in table form. Careful notes have been made in all cases, and these are summarized in the following paragraphs.

In general, the treated material was not much browner than untreated material in the early part of the dormant period. Somewhat later the color differences were very striking, the treated cortex being the deeper brown in practically every case. Toward the close of the season the differences again became less noticeable, and in the last few werks differences could seldom be 

observed. At this time of the year (March) the untreated material became much browner in a given period of time than at the beginning of the dormant season. In all cases where the material had been heated to $100^{\circ} \mathrm{C}$. for a short time, it remained greenish for over 24 hours. The brown color of unheated cortex appeared soon after grinding. The deeper. the color, the sooner it appeared on the ground tissue exposed to air.

The ground ash cortex did not become brown either with or without treatment. Different varieties of the apple showed variations in their behavior as far as coloration of the ground treated and untreated tissue was concerned. For example material from the Woodmanse was usually somewhat lighter in color than Ben Hur; and King David generally gave the darkest coloration. Just what causes these variations is not definitely known. Cortex from weak twigs usually remained greener for a longer time than cortex from vigorous twigs taken from the same tree. Cortex from similar twigs taken from similar trees of the same variety, showed about the same shade of brown when the same treatments were given.

The nature of the stimulant used affects the coloration to some extent, e. $g_{\bullet}$, injured material becomes deeper brown than dry material. The cortex from twigs bathed in alcohol remained greener than etherized material. In general the more intense the treatment if not too intense, the deeper the brown color of the cortex, and the quicker it is attained after grind- 

ing up. In a few cases, strong stimulants applied very late in the season inhibited the formation of the brown color, i.e., the untreated material was a darker brown than the heated.

Results similar to those just given, were obtained by allowing the ground up cortex material to oxidize the fresh colorless pyrogallol solutions to purpurgallic acid which is a deep cherry red (Kastle 55). The methods used and the nature of the results obtained may be illustrated by the following example: After preliminary treatment of the twigs, the cortex was scraped from the wood and ground up. Five grams were added to each of several vials. Some vials received heated cortex, and others received no cortex at all. To each of these vials, $50 \mathrm{cc}$. of a 0.5 per cent freshly prepared pyrogallic acid were added. All were then placed in an oven at $35^{\circ} \mathrm{C}$. Observations were made after a few hours. In a specific case the preliminary treatments were, 1 ether, $\frac{1}{2}$ ether and check. The notes obtained after the cortex material had acted on the pyrogallic acid solution for two hours foliow: "In all cases the cortex has settled, leaving the clear liquid above. In every vial, except the one which had no cortex, this liquid has separated into two distinct layers, the lower one being yellow, while the upper is reddish brown. In the vials with the untreated material, the upper brown zone is not quite as broad as the lower; in the $\frac{1}{2}$ ether vial, the upper layer is about twice as broad as the lower; and In the 1 ether vial, the upper layer is three times as wide as 

the lower. The yellow layer is the same shade in all cases. The upper layer becomes darker as it gets broader, being lightest in the untreated and darkest in the 1 Ether vial. After ten hours all vials were uniformly colored. The yellow layer disappeared entirely and the liquid was very opaque."

This method of determining the oxidizing activity of the twig tissue is probably a little more quantitative than the one given above.

In this connection it might be mentioned that treatments which caused the cortex to become deeper brown than untreated material usually caused an earlier growth of the buds. When the difference in color between treated and untreated cortex was slight or not noticeable at all, the treated buds opened just about the same time as untreated. In those cases where the ground cortex from treatedmaterial did not become as brown as non-treated cortex, the untreated opened before the treated.

\section{Sugar in Treated and Untreated Twigs.}

In the foregoing experiments the enzyme found in treated twig tissue proved to be more active than those in untreated twigs when allowed to act on foreign material.

When the tissue is ground up as was done in the precoeding experiments some of the cells are ruptured, and as a result their protoplaswic organization is disturbed. Ferments might behave differently after being freed, than they would under normal protoplasmic control. (Palladin 84, 85, 86). How do the enzymes 

respond to treatments given the tissue, when they are allowed to act under protoplasmic control in living tissue? In other words, how do they affect the insoluble storage substances, especially starch, which are naturally found in the tissue? To answer these questions was the main object of the following experiments.

The material used, the manner of collecting the twigs and dividing them into similar groups, as well as the preliminary treatments given, are the same as in the foregoing experiments.

After the twigs had received the preliminary treatments 1.e. the application of the rest period-breaking agent, they were ground up in the food chopper. The entire twigs were used. Duplicate 10-gram samples of treated and of untreated ground material were weighed out. These were then placed in coarse filter papers. Each sample was leached with $100 \mathrm{cc}$. of cold water. The water was poured over the ground material as quickly as possible so that the entire $100 \mathrm{cc}$. was added before any water came through the filter.

The extract passed through the filter very rapidiy so that whatever material came through must have been very soluble. In some cases a second and a third $100 \mathrm{cc}$. of extract were obtained from the same material, each $100 \mathrm{cc}$. being kept separate. The presence and amount of sugar in the extract was detemined by means of Fehling's solution which was prepared according to the official Methods of Agricultural Chemists (U. S. Department of Agriculture). Equal quantities of Fehling's, usually 1 or $2 \mathrm{cc}$. , were added to 

equal quantities of extract, usually 5 or $10 \mathrm{cc}$. These mixtures were boiled for at least two minutes after which they were allowed to cool. All determination were made in duplicate. The color of the supermatent liquid after the precipitate had settled was used as a basis for estimating the relative amounts of sugar present. A jellow liquid indicates that there is more sugar present than is required to reduce the Fehlings solution; a bluish color shows that the sugar which was present was insufficient to reduce the Fehling. The following simple experiment illustrates what has just been said.

Several $5 \mathrm{cc}$. samples of an apple twig extract were taken as follows: (1) Before diluting; (2) after diluting to twice its original volume; (3) to four times its volume; and (4) to eight times its original volume. To each of these samples $1 \mathrm{cc}$. of Fehlingls was added. They were then heated for several minutes. After cooling and settling, the liquid in (1) was yellowish; in (2) a yellowish green; in (3) a bluish green; and in (4) a blue. The amount of precipitate was greatest in (1) and least in (4). The color of the fresh extracts was another basis for estimating the relative amounts of sugar contained in them. The apple twig extract was generally light yellow to deep orange. By diluting the deeper colored extract from two to twelve times with water, the light color would be obtained. Before dilution the deeper colored extract showed more sugar than the light colored; after dilution, both contained the same quantities of sugar. 

The results of these sugar tests substantiate those obtained with the enzyme tests. The following determinations which are typical, show the nature of the results.

1. Jonathan apple twigs were collected sept. 23, 1913. Some were etherized and some remained untreated. Sugar determinations were made twenty-four hours after treatment. The same experiment was repeated on October 28 , and on January 12; 1914. In the first case there was no noticeable difference in the amount of readily soluble sugar of etherized and of untreated twigs. A month later, the treated twigs had more sugar than untreated ones. In the last determination, both sets of twigs again showed similar amounts of sugar.

2. On December 7,1913 , some Jonathan apple twigs were immersed in 10 per cent aloohol for fifteen hours, some were dried at $35^{\circ} \mathrm{C}$, for fifteen hours, some were etherized twenty-four hours and some remained untreated. twenty-four hours the treated twigs showed more sugar than the untreated. On February 12, 1914, the same treatments were again applied to Jonathan twigs. In this case the untreated twigs showed as much sugar as the treated.

3. King David apple twigs were collected on February 8, 1914. Some were etherized for twenty-four hours, some were bathed in 10 per cent alcohol for fifteen hours, some in 0.5 per cent hydrochloric acid for fifteen hours, and some remained untreated. The untreated material showed most sugar; the etherized and the HCl-bathed twigs, a medium amount, and the twigs bathed in alco- 

hol showed the least sugar.

4. On November 8, 1913, Payne's Keeper apple twigs were collected. Some were injured by beating the internodes wth a knife handle, some were untreated. After twenty-four hours, the injured twigs had the most sugar. When the same experiment was repeated on March 9, 1914, the untreated material contained the most sugar.

A number of other experiments might be cited, all of which indicate that agents such as etherization, warm water bath, alcohol bath, hydrochloric acid bath, drying, mechanical injury, etc., when applied during early winter, increase the amount of readily soluble reducing sugars within twenty-four hours after the applications are given. If the treatments are given somewhat later in the season, the stimulants will have little or no effect on increasing the amount of sugar. If delayed until very late, the untreated twigs will actually have more soluble sugar than similar treated material. While a given strong intensity of a certain treatment applied late in the season might inhibit the formation of soluble material a less intense application made at the same time would actually cause the production of more sugar than in case of untreated material

In adition to using many varieties of apples, mulberry, oak and ash twigs were also used for these sugar determinations. The specific effects obtained vary, among other factors, with the species and varieties of a given species as well as the 

nature of the agent.

These results have not been given in table form, because they could not be expressed accurately in that way. Quantintative determinations will be made in future experiments along this Iine.

D. Miscellaneous Experiments and Observations.

A number of experiments and observations were made which do not fall under the previous classes. Those which have a bearing on the main problems will be given at this time. 1. Does Ether Have a Desiccating Influence?

As previously mentioned some authors seem to think that all treatments given to break the rest period, especially otherization, have a desiccating effect. Desiccation as used in this paper denotes the loss of water from the tissue as evidenced by loss in weight. The term may be used to refer to the phenomenon observed when water leaves the cell to go into the intercellular spaces as it does when ice is formed. In that case, the tissue need not necessarily lose weight since the water remained within the twig. (Chandler 2I).

A dose of ether which results in breaking the rest period has practically no desiccating effect on the tissue as may be seen from the data in table No. 14, page 58. These data are typical. The figures show that the untreated twigs lose just as much as the treated. Very little moisture is lost in any case. When a very strong dose of ether is used, large beads of liquid 

Table No. 14

Weights in Grams of Etherized and Untreated Apple Twigs.

\begin{tabular}{|l|l|l|l|l|l|l|}
\hline \multirow{2}{*}{ Variety } & \multicolumn{2}{|c|}{ Untreated } & \multicolumn{2}{c|}{$\frac{1}{2}$ Ether } & \multicolumn{2}{c|}{ I Ether } \\
\cline { 2 - 7 } . Before* & After* & Before & After & Before & After \\
\hline Red June & 48.45 & 48.10 & 52.25 & 52.00 & 49.60 & 49.30 \\
$\begin{array}{c}\text { Payne's Late } \\
\text { Keeper } \\
\text { Woodmanse }\end{array}$ & 41.20 & 40.95 & 43.50 & 43.00 & 40.50 & 40.35 \\
& 52.05 & 51.85 & 52.00 & 51.85 & 53.05 & 53.00 \\
\hline
\end{tabular}

*The twigs were weighed when collected and again after the preliminary treatment which lasted 24 hours. 

may exude from the tissue so treated. Such large doses, however, do not break the rest period but they injure the twig beyond recovery.

2. Color Change in Etherized and Untreated Apple Twigs.

On November 24, 1913, and on March 9, 1914, one year old Ben Davis apple twigs were collected. Some were etherized for twenty-four hours, some remained untreated. After an interval of five days in each case all twigs were immersed in pure water which had a temperature of $35^{\circ} \mathrm{C}$. The notes taken in the first experiment read as follows: "After six hours from time twigs were placed in water the bud, scales and the shoulder just below the buds of the etherized specimens are becoming yellowish; the internodes remain normal reddish brown. The untreated twigs are normal reddish brown throughout. After eighteen hours all atherized twigs are entirely yellow. All untreated twigs are normal redish brown throughout. After three days the bud scales and the bud shoulders of the untreated twigs are becoming yellow. After five days the untreated twigs are entirely yellow, the color being similar to that shown by etherized twigs after eighteen hours." In the last experiment the following observations were recorded: "After twenty-four hours the bud scales and bud shoulders of treated twigs show a yellowish color while the remaining parts of the twigs are reddish brown. The untreated twigs are reddish brown throughout. After two days the treated twigs are yellow throughout except for a few isolated areas in the internodes 

which show the reddish brown tint. These unchanged areas are confined to the internodes nearest the terminal buds; the internodes near the bases of the twigs are uniformly jellow. A few of the untreated twigs are just beginning to show jellow on the bud scales and bud shoulders. All internodes are still reddish brown in color. After elght days about one-fourth of the surface of untreated twigs is still redish brown in the internodes. All etherized twigs are jellow throughout, They have been so since the fourth day."

These experiments indicate that etherization tends to hasten changes within the twig which would normally occur in untreated material.

3. Amount of Sugar and Growth.

Jonathan apple twigs were collected on February 8,1914 Some were etherized twenty-four hours; some remained untreated. The twigs remained in the respiration chamber for three days after which some etherized and some untreated twigs were placed in the greenhouse in beakers containing $50 \mathrm{cc}$. water. The cuts on the bases of the twigs were renewed every day so they would take up water readily.

After four days, the buds on the etherized twigs began to burst; those on the untreated twigs remained dormant. Sugar determinations made at this time (using the method previously described) showed that the etherized material contained more sugar than the untreated. After a few more days the buds of the untreated twigs burst open and at the end of fourteen days the leaves of 

unetherized twigs had outgrown those of the treated material. This time, the sugar determinations indicated that the untreated twigs had the larger amount of sugar. After another four or five days the leaf growth in all twigs came to a standstill. Again the relative amounts of sugar in both treated and untreated twigs was determined. Both sets showed a similar amount. 4. Respiration and Growth.

Jonathan apple twigs were collected on February 9, 1914. Some lots were etherized for twenty-four hours; some remained untreated. After this preliminary treatment, all were put in the respiration chamber. During the first few days the etherized twigs gave off more $\mathrm{CO}_{2}$ than untreated twigs. During this period, on the second day, some of the treated and some untreated lots were removed from the respiration chamber and, after receiving the cuts at the bases of the twigs, they were placed in the greenhouse in beakers containing water. The twigs were allowed to grow for a period of four days after which they were immersed in a strong formalin solution, in order to stop further growth, and at the same time preserve the general appearance of the growth already made. After the fourth day, the $\mathrm{CO}_{2}$ production of the etherized material had fallen below that of the untreated. (Cf. curve V, plate 5). on the sixth day, i.e. during that period when untreated twigs were producing more $\mathrm{CO}_{2}$ than treated, some lots were again removed from the respiration chambers and placed under conditions favorable for growth. After growing four days, these twigs were immersed in 

formalin as in the first case. The following observations were made: "The etherized twigs which are supplied with warmth and moisture and other conditions necessary for growth within a few days after treatment have made more growth during four days than similar etherized twigs which were not placed under favorable growing conditions until six days after being treated. The untreated twigs in the first case have made slightly less growth than those in the latter case." In other words, the respiratory activity of the tissue which may be determined while the twigs are apparently dormant, serves as an index to the relative amount of growth which would occur if the tissue had favorable conditions for growth. 5. Fungi on Treated Twigs.

Whenever the cut surfaces of etherized twigs were left exposed in a damp basement room, the fungi Aspergillus and Penicillium grew abundantly on them. Under the same conditions, the untreated twigs showed no infection by the molds except in a fer cases during the close of the dormant season. 6. Color Changes in Water Extract of Twigs.

Decided color changes were observed in the water extract of the twig material. The following case is typical. King David apple twigs were collected March 18, 1914. Some were etherized and some remained untreated. Cold water extracts were then made of both lots using $100 \mathrm{cc}$. water to leach $10 \mathrm{gr}$. ground twig material. A number of test tubes received $10 \mathrm{cc}$. each of the extract from treated twigs; others received $10 \mathrm{cc}$. of 

extract from untreated material. The subsequent treatinents which were given as well as the observations made are recorded in the table No. 15 .

The heating prevented any color changes. The addition of toluene ". had a similar effect. Where no special treatments were given, the changes were quite marired, more so than the table indicates. The extract from theetherized material which had been the darkest colored in the beginning was the lightest after five days. The changes were apparently due to bacteria.

7. Gas Formation on Twigs.

On February 27, 1914, some one year old Red June twigs were collected. Similar lots were immersed in pure water, in 5 per cent, in 10 per cent and in 20 per cent alcohol respectively. After fifteen hours the following observations were made: "The twigs in 5 per cent alcohol are entirely covered with small gas bubbles; the material in 10 per cent alcohol and that in pure water has fewer bubbles; that in the 20 per cent alcohol has only a very few, $\mathrm{s}$ scattered here and there. Similar results were obtained at various times."

8. Gas on Ground Cortex Preparation.

Some Jonathan apple twigs were collected on December 3, 1913. Some were immersed in 10 per cent alcohol for fifteen hours, some were bathed in water during the same period. After two days the material was prepared for the diastatic enzyme test as previously described. The preparation from material which had been treated with alcohol becare covered with foam after twelve 

Table No. 15

Color Changes Occurring in Water Extract of Ftherized and Untreated King David Apple Twigs.

\begin{tabular}{|c|c|c|c|c|}
\hline \multirow{2}{*}{$\begin{array}{l}\text { Treatment } \\
\text { of } \\
\text { extract }\end{array}$} & \multirow{2}{*}{$\begin{array}{l}\text { Source } \\
\text { of } \\
\text { extract }\end{array}$} & \multicolumn{3}{|c|}{ Color of Extract } \\
\hline & & At Outset & After 2 days & After 5 days \\
\hline None & $\begin{array}{l}\text { Untreated } \\
\text { Etherized }\end{array}$ & $\begin{array}{l}\text { Iight yellow } \\
\text { Dark yellow }\end{array}$ & $\begin{array}{l}\text { Iight yellow } \\
\text { Dark yellow }\end{array}$ & $\begin{array}{l}\text { Iight yellow } \\
\text { Very light } \\
\text { yellow }\end{array}$ \\
\hline $\begin{array}{l}10 \% \text { toluene } \\
\text { added }\end{array}$ & $\begin{array}{l}\text { Untreated } \\
\text { Etherized }\end{array}$ & $\begin{array}{c}\text { Yellow } \\
\text { Dark yellow }\end{array}$ & $\begin{array}{c}\text { Yellow } \\
\text { Dark yellow }\end{array}$ & $\begin{array}{c}\text { Yellow } \\
\text { Dark yellow }\end{array}$ \\
\hline $\begin{array}{l}\text { Heated } \\
\text { to } 100 \mathrm{c} .\end{array}$ & $\begin{array}{l}\text { Untreated } \\
\text { Etherized }\end{array}$ & $\begin{array}{c}\text { Yellow } \\
\text { Dark Jellow }\end{array}$ & $\begin{array}{c}\text { Yellow } \\
\text { Dark yellow }\end{array}$ & $\begin{array}{c}\text { Yellow } \\
\text { Dark yellow }\end{array}$ \\
\hline
\end{tabular}



hours; none appeared on the preparation from material which had been immersed in cold water.

9. Effect of Etherization of Frozen Seeds. During 1912-13 Wiggans (111) carried on some studies concerning the rest period of seeds. In one experiment, he determined the effect of freezing and etherization of seeds which had been previously soaked in water for three hours. After treatment, the seeds were allowed to germinate between moist filters. At least one hundred seeds were used in each case. The freezing temperature was a few degrees below $0^{\circ} \mathrm{C}$. Btherization was carried out immediately after freezing. A somewhat weaker dose of ether was applied than in the experiments described in this paper. The results obtained in the germination tests are summarized in the following table. (No. 17, page 66).

It will be seen that the freezing of soaked seeds has reduced the percentage of germination in all cases below that of seeds which were soaked but not frozen. But if the freezing is followed immediately by etherization, the reduction in the percent of germination is not so marked. In other words, the other treatment has apparently hindered, or counteracted to some extent, the destructive processes which were initiated by freezing. (It should be mentioned that all seeds of a given variety were: scaked at one time. One-third of the entire lot were allowed to germinate without further treatment, while the remaining two-thirds were frozen. Of these frozen seeds, one-half were allowed to 

Table No. 17

Percentage Germination of Seeds of Different Species Treated in Various Ways.

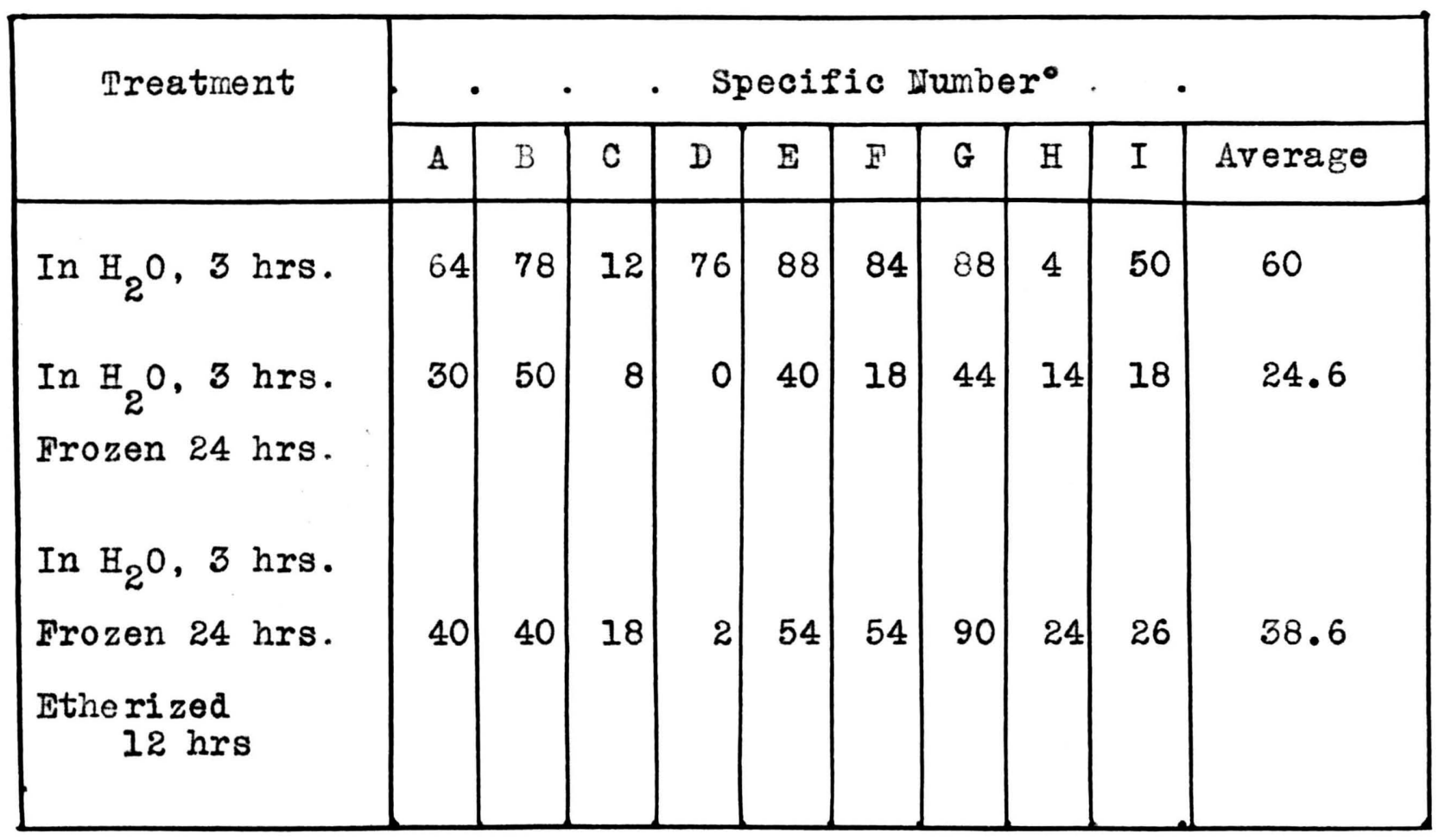

\footnotetext{
$A^{\circ}$ Zea Mays I.

B Phaseolus lunatus I.

C P. vulgaris I.

D Citrulus vulgaris schrad.

E Cucurbita maxima Duchesne.

F Spinaciat oleracea

$G$ Raphanus sativus

H Hibiscus esculentus I.

I Allium cepa I.
} 

germinate while the remainder were etherized before placing them under conditions suitable for germination).

Results similar to those given in the above table were obtained when the seeds were allowed to soak for six instead of three hours. The experiments with seeds are of interest because they suggest a very interesting effect of etherization.

E. Influence of Various Agents on the Rest Period of Plants.

In connection with each experiment which has been described in the foregoing pages, some treated and some untreated twigs were placed in beakers containing water and put in the greenhouse where they were allowed to grow. The time when the buds opened was noted in all cases.

The results in general were similar to those obtaineded by previous investigators. It was found that during the very early part of the dormant season, the rest period was not as easity broken as later on. Toward the close of the dormant season, it was found difficult to get any marked stimulation. Heary dosage of a given agent which produced earlier growth in twigs during December or early January, was found to injure the twigs and buds if given later in the season. The specific behavior of some twigs has already been referred to in connection with some of the experiments.

A few observations might be of interest in this connection.

In some cases a very strong dose of ether has stimu- 

lated the terminal bud only, while a dose only half as strong caused the laterals as well as the terminals to grow earlier than untreated buds.

Twigs which were frozen pushed their basal buds before those nearer the terminal.

In many cases, a given àose of ether stimulated the leaf buds while the flower buds were killed by the treatment.

In several cases mechanical injury just below or near a bud caused that bud to burst into growth while the buds above and below remained dormant. As a rale, desiccation produced the most uniform results, i.e., the drying caused all lateralsas well as terminals to come out about the same time. Usually on untreated twigs the lateral buds came out very irregularty some of them coming out several days before others.

On January 16, 1914, a number of similar, vigorous, one year old King David apple twigs were collected. All were about $75 \mathrm{~cm}$. long. Some were left entire; some were cut in half; while in other cases the terminal one-third was cut off. The lower cut surfaces of each lot of twigs were put in beakers of water and placed in the greenhouse. The photograph, plate 8 , shows the general appearance of the twigs after one month. The twigs at A were those which were left entire. Very few terminal buds had pushed. The laterals in the lower portions of the twigs had made a good growth. Most of the laterals further up on the twig were dormant. The lower two-thirds of some of the 



\section{Plate 8}

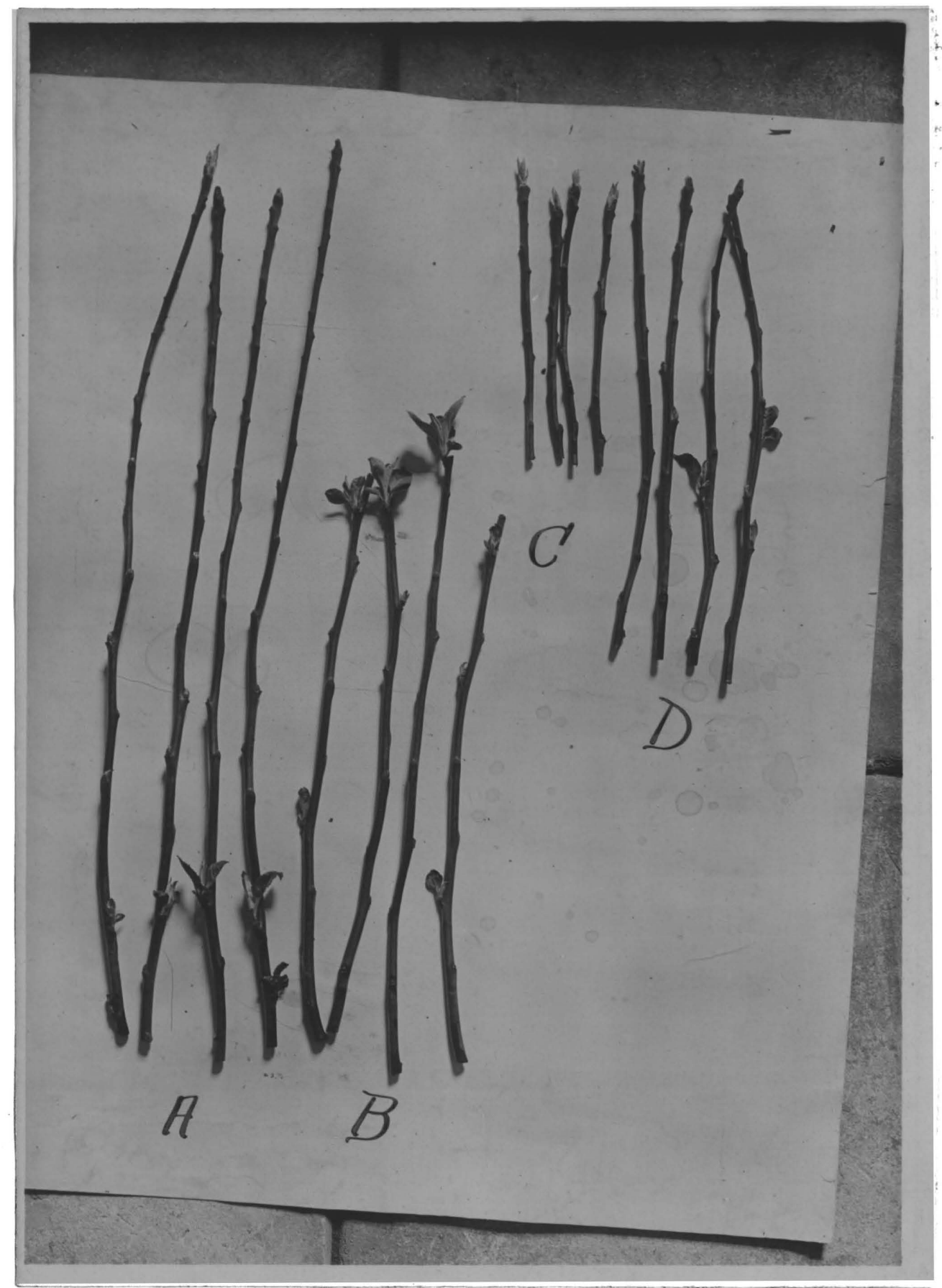

Growth of Various Sections of Similar Apple Twigs. 

twigs are shown at $\underline{B}$. In this case the buds nearest the injured surface had made a very vigorous growth. The remaining lateral buds had also made more or less growth. The twigs at $\underline{c}$ are the upper parts of those shown in $\underline{B}$. The terminal portions had made no lateral growth. The terminal buds, however, had pushed somewhat more vigorously than those at $\underline{A}$ or $\underline{D}$. The upper half of those twigs which were cut into two equal parts, is shown at $\underline{D}$. In these, the terminals had made some growth. Some of the lateral buds had pushed rather vigorously, and many of them had made a feeble growth.

The behavior of these twigs indicates that the water supply which reaches the buds is one of the important factors in their development. It should be mentioned that the buds in all cases were fully turgid.

On Jamary 22, 1914, a number of very vigorous one year twigs were collected from a Jonathan apple tree. Some very weak twigs were selected from the same tree. The former were over one meter long, while the latter were only about 15 to $20 \mathrm{~cm}$. These twigs were placed in beakers containing water and they were allowed to grow in the greenhouse. The photograph, plate 9, shows the growth made by each set after one month. It will be seen that the terminal buds of the vigorous twigs (A), have made much more grow th than those of the weak twigs (B). The former opened within a few days after they were brought into the greenhouse; the latter first burst after two weeks. 

Plate o.

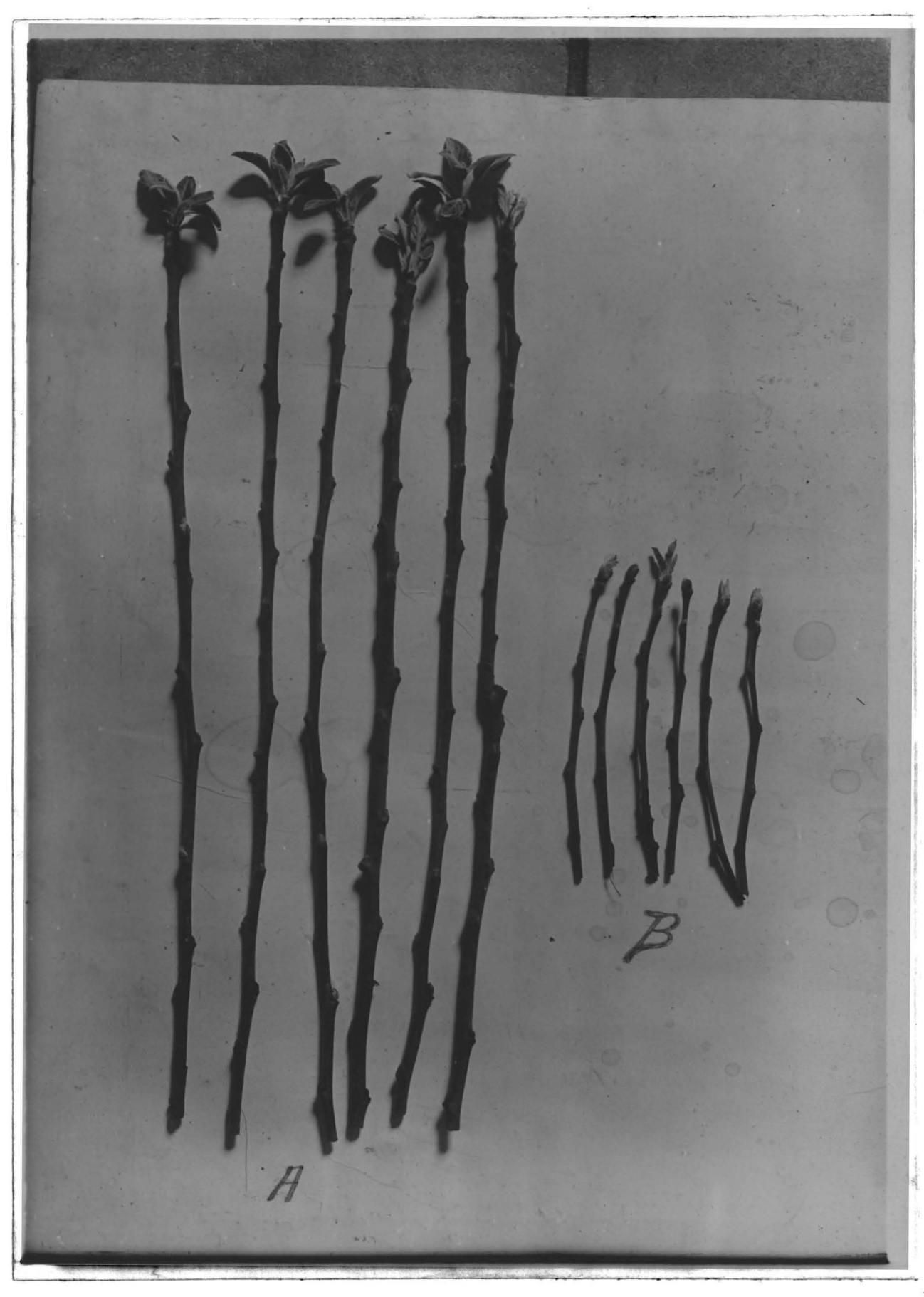

Strong (A) and weak (B) Twigs After one Month's Growth. 

Did the tall twigs finish their rest before the weak twigs? Did they have a rest period at all, or did they stop growth because they were forced to do so by the cold woather? The terminal buds were not so well covered as in the case of the weaker twigs. Apparentiy growth in the strong twigs stopped rather suddenly so that no time was left to finlsh out the buds as in the case of weaker twigs.

NEW INETHODS FOR BREAKING THE REST PERIOD.

A few new methods of forcing were employed with more or less success. In no case was any attempt made to determine just the right dose to give for the most effective results. There can be little doubt that for each treatment there is some optimum which varies with the species, the season and with other factors. The object of these tests was to determine whether the treatments given would actually stimulate growth or not. Relatively little attention was given to the degree of stimulation.

Immersing apple twigs in $0.25,0.125, .0625$ or .03125 per cent $\mathrm{CuSO}_{4}$ for twelve hourspn December 7,1913 , caused earlier growth in twigs so treated than in untreated material. The stronger the concentration the better the results. The same treatment applied to Forsythia at the same time proved toxic to the buàs. 

Immersing in 0.5 per cent HCl for sixteen hours proved effectivein forcing apple buds as well as Forsythia. The

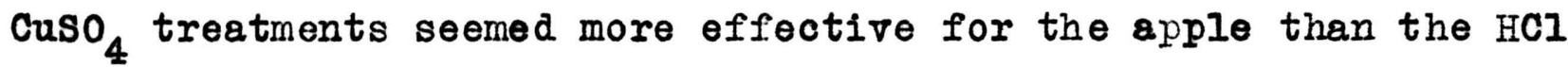
acid bath.

On December 17, 1913, Fraxinus Ornus twigs were immersed in 5 per cent, 1 per cent and 0.5 per cent oxalic acid for twelve hours after which the $y$ were placed in water in the greenhouse. After twenty-five days, the terminal buds of twigs treated with the one per cent and the 0.5 per cent solutions began to push. The untreated twigs remained dormant. Acetic acid baths gave similar results. Quercus coccinea twigs did not respond to treatments similar to those given the ash.

A number of different solutions were tried for their forcing qualities. Ash, oak, apple, plum and maple twigs were used. The twigs were immersed in the different solutions for twelve hours. The treatments were given on January 20, 1914. The treatments which proved effective were as follows: For ash, 5 per cent $\mathrm{NaNO}_{3}$ and 5 per cent ammonium oxalate; for maple, 0.5 per cent $\mathrm{KCl}$; for plum, 1 per cent ammonium oxalate, 0.5 per cent $\mathrm{KCl}, 5$ per cent $\mathrm{NaNO}_{3}$ and 0.5 per cent CusO ; for apple, 1 per cent and 0.5 per cent Cuso $_{4}$ and 1 per cent $\mathrm{KCl}$.

Good forcing results were obtained with $\mathrm{MnO}_{2}$ treatments. On January 19, 1914, ash, apple and oak twigs were dipped In $\mathrm{MnO}_{2}$ paste made of powdered $\mathrm{MnO}_{2}$ and water. The paste adheres 

to the twigs and forms a slate colored coating when dry. The treated twigs were placed in a greenhouse in water along. with untreated material. The accompanying photograph (Plate 10) shows the results one month after treatment. The buds on the treated ash twigs had swollen very much as compared with those on untreated twigs. The former twigs had also formed an abundance of callus tissue. The treated oak twigs had pushed their buds much more than twigs which received no treatment. Apparently, the apple does not respond to the $\mathrm{WnO}_{\mathrm{g}}$ treatment so late in the year. It should be mentioned that the $\mathrm{HnO}_{2}$ might influence the twig indirectly by absorbing heat due to its dark color. (Whitten 109). The apple, however, is normally affected by warmth and the $\mathrm{MnO}_{2}$ treatment was not toxic because both check and treated buds pushed about the same time.

\section{DISCUSSION OF RESULTS.}

Many of the results presented in this paper offer experimental proof in support of the theory of Klebs which has been mentioned previously. The rest period-breaking agents do apparently stimulate fermentative activity. In most cases when the diastase enzymes are made more active, earlier growth is induced. However, this is not always the case. A striking example is found in the case of the ash. This species has a very high diastatic activity, yet if forces with much difficulty. The same phenomenon holds in case of several varieties of apples 

Plate 10

$4 \operatorname{lag}_{9}$

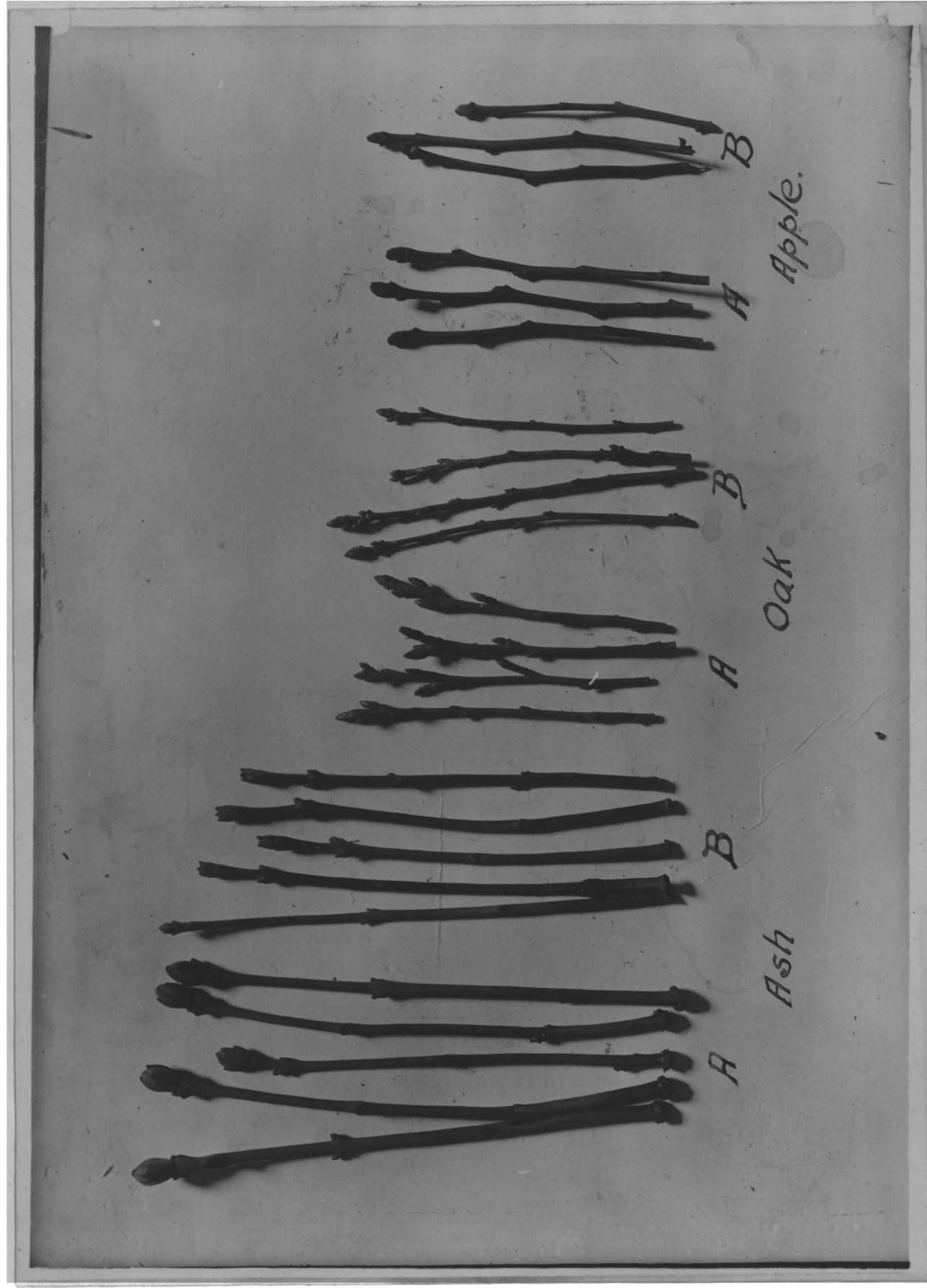

ऐ

E

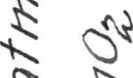

e 5

N

के इ

$e^{x}=x^{2}$

$a$ i

है

है

1 $\approx$

J

$\frac{2}{4} \frac{5}{5}$ 

though not to so great an extent. How can we account for these results?

By referring to the figures in table 4 , page 18 , it is seen that etherization has very little effect in stimulating the $\mathrm{CO}_{2}$ production of ash. It is further noted that the ash tissue oxidized very slowly. It has also been mentioned that some varieties of apples oxidize their tissue more readily than others. Those which oxidize most are most easily forced.

The respiration curves of the Jonathan apple likewise indicate that the increased amount of $\mathrm{CO}_{2}$ produced as a result of treatments varies with the different times of the season. When the stimulation is most marked the forcing is most efficient.

It is quite possible that a given resting tissue may have sufficient soluble material to support growth as has been pointed out by Johannsen (53, p.44). Treatments in such cases may produce still more sugar than is already present. However, the food must be usable to be of value to the plant. Before it can be used at all, energy must be made available. In order to furnish energy, material must be oxidized and the oxidizing enzymes are responsible for this oxidation process to a large extent. Again not all food material is readily oxidized. Qertain substances e.g. starch must first be changed to sugars before combustion occurs. In some plants $1 . e .$, in those where sugar is normally abundant, a rest period-breaking agent needs only to stimulate the oxidizing forces; while in others it becomes neces- 



\section{4}

sary to set in action those forces which convert insoluble food into readily oxidizable and therefore energy yielding material, as well as to stimulate the oxidizing agents themselves.

The question may arise - "Do these agents affect the enzymes directly, or indirectly by first influencing the general protoplasmic organization? "The more growth there is, the greater the enzyme activity, and hence it might be said that growth has already been started as a result of the stimulation given by the rest period-breaking agent, and therefore one would naturally expect enzyme activity.

There is no reason to suppose that the rest periodbreaking agents single out specific organisms of the protoplasm such as enzymes. Many other portions of the "protoplasmic makeup", a phrase which covers much that is unknown, may be affected at the same time. We simply have an easy method of determining the enzyme activity but we have no sure way of knowing whether or not other parts of the protoplasm are not affected at the same time that the enzymes are. On the other hand, it is conceivable that such specific portions of the protoplasm as enzymes could be affected directly by outside agencies. In other words, in one case the stimulant may directly affect the seat of protoplasmic activity - whatever that may be - which in turn influences all other parts; while in another case, the stimulant may indirectly affeot the protoplasm by first influencing some specific portion of its structure. 

We might consider the complex wheels and cogs and other parts of a clock as the protoplasmic structure. If we wind the spring, energy is stored up by which the entire mechanism is set in motion. This spring may be considered as the seat of protoplasmic activity which brings about the movement of all other parts of the clock. The rate at which this spring unwinds is determined by a pendulum. We may set this part so the clock goes fast or slow. In this case, we are affecting a specific portion of the mechanism directly, and as a result of that effect the entire structure is, in turn, made to respond.

All experiments seem to indicate that etherization and other means of breaking the rest period intensify and hasten the normal physiological processes. As a result, metabolic changes are carried out in a much shorter time than under ordinary conditions. This is shown especially and in a striking manner by the experiment in which treated and untreated twigs were kept under water. All other experiments show a similar phenomenon.

\section{SUMMARY.}

Plants normally do not respond to favorable growing conditions during their rest period.

The rest period is not a condition of total inactivity. Reproductive functions (healing processes), chemical changes, and respiratory processes go on continually even during the period of rest. 

The agents which break the rest period increase respiration. The amount of increase in respiration depends, among other factors, upon the species, the agent used, the intensity of treatment, and upon the time of application of the stimulant.

The greater the stimulation of $\mathrm{CO}_{2}$ production, the earlier the treated plant begins to grow as compared with untreated tissue.

When a treatment fails to stimulate $\mathrm{CO}_{2}$ production, it does not cause a breaking of the rest period. Rest period-breaking agents stimulate the fermentative activity of the tissue. The degree of stimulation depends upon the specles, the variety of a given specles, the agent used, the intensity of the treatment, the time of treatment, the interval after treatments as well as other factors. Stimulants in some cases may diminish enzyme activity.

Usually, an increase in diastatic enzyme activity is accompanied by earlier growth. A marked increase in oxidizing action is nearly always accompanied by earlier growth. Whenever the fermentative action is inhibited, growth is delayed.

Sugar determinations of treated and untreated twigs show that the ferments dissolve starch within the tig tissue. The amount of increase in sugar varies with factors which influence the diastatic enzyme activity. 

that treatments given to break the rest period hasten normal metabolic processes. When treatments are too strong, these processes may be inhibited somewhat or the tissue may be injured permanently.

In general forcing agents are more effective in the middle of the winter than in late fall, or in early spring. The specific action of a rest period breaking agent depends upon the species, the varieties of a given species, the vigor of the resting tissue, the seasonal influences, and many other factors.

The factor of abundant water supply is an important one in inducing earlier growth of dormant buds.

\section{CONC LUS IONS.}

As previously mentioned, the results given in this thesis were secured from experiments which were in progress for a. single season only. The facts obtained must be verified and established more firmly before definite conclusions can be drawn from them.

It may be said, however, that the results secured so far seem to indicate that an efficient rest period-breaking agent must influence the physiological processes in such a manner that the enzymes are stimulated, so that an abundance of food is not only made available but also made to yield energy. Stimulation of those agencies - the oxidizing ferments - which convert food 



\section{9}

into energy is of prime importance.

\section{AC KNOWLEDGEMENTS.}

I wish to express my sincere thanks for the helpful suggestions made by Dr. W. I. Howard, Dr. G. h. Reed, and Dr. J. C. Whitten. Their interest in the problem has been a source of much encouragement. 



\section{BIBLIOGRAPHY.}

1 Abderhalden, E., \& Dammhahn. Peptolytic ferments in germinating and ungerninating seeds. Ztschr. Physiol. Chem. 57 (1908) pp. 332-338

2 Agulhou, $H$. Action of light upon enzymes.

E. S. R. $27, p \cdot 110$

3 Appleman, Physiological behavior of enzymes and carbohydrate transference in after-ripening of potato tubers. Bot. Gaz. 52 pp. 306-315

4 Armstrong, H. E., \& E. F. Origin of osmotic effects. III.The function of hormones in stimulating enzymatic change in living structures.

Proc. Roy. Soc. Ser. B. 82 (1910) No. B 559.pp.588-602

5 Armstrong, H. F. The stimulation of plant growth.

Jour. Roy. Hort. Soc. 1912 No. 1 pp. 17-21

6 Agmard, J. (See Howard (47) p. 24 )

7 Bach and Chodat. 0xydations vorgunge in der lebenden zelle. Zentrabl. f. agrik. Chemie (1908) 87, pp. 168-177

8 Ballard, W. S., and Volck, W. H. Winter spraying with solutions of nitrate of soda. Journ, of Agr. Research, Dept. Agr. Washington, D. C., Vol. I, No. 5 (1914】

9 Bayliss, W. W. The nature of enzyme action. (IongmannsGreen \& Co. (1911)). 

10 Beltz, W. J. The effects of etherization on plants.

E. S. R. 16 , p. 978 .

11 Bernard, Claude. (See Johannsen (53) p. 65).

12 Berthold, Unters. z. Physiologie d. pflanzel. Organization. (Book) Bd. II Chap. 5, Bd. III p. 251.

13 Bolle, J. Experiments to determine effects of ether and chloroform upon plants.

E. S. R. 16 , p. 159 .

14 Borowikow, G. A. Uber die Ursachen des Wachstum der Pflanzen Biochem. Ztschr. 48, pp.230-246, also E. S. R. $29, \mathrm{p} .26$

15 Bos, Wirkung galvanischer strome auf Pflanzen in der Ruheperiode Biolog. Zentrabl. (1907) 27, No. 2.

16 Brown and Morris. On the chemistry and physiology of foliage leaves. Journ. Chem. Soc. Trans. 1893, p. 637.

17 Butkewitsch, w. Upon the occurrence and function of proteolytic enzymes in germinating seeds. Ber. d. d. bot. Ges. 18, (1900) pp. 358-364. ztschr. Physiol. Chem. 32 (1901) 1-53. (On the transformation of starch in plants). Biochemische ztschr. 10 (1908) pp. 314-344

19 Butler, 0. A note on the significance of sugar in tubers of Solanum tuberosum. Bul. Torrey Bot. Club 40 (1913), p. 110. 

20 Chandler, W. H. Sap studies of horticultural plants.

Research Bul. No. 14, Mo. Agr. Exp. Sta. (In press).

21 Freezing of plant tissue.

Research Bul. No. 8, Mo. Agr. Exp. Sta. (In press).

22 Chapin, P. Einfluss der Kohlensaure auf das Wachstum.

Flora, 91, pp. 348-379.

23 Clark, E. D. Plant oxldases.

Diss. Columbia Univ., N. Y. (1910).

24 Clausen, H. Beit. zur Kenntnes der Atmung der Gewhchse u.

des pflanzlichen stoffwechsels.

Landw. Jahrb. 19, p. 893.

25 Cohnheim, 0. On enzymes (Book) also

E. S. R. 27, p. 202 .

26 Copeland, E. B. (Respiration and poisons).

E. S. R. 14, p. 121 .

27

Chemical stimulation and the evolution

of $\mathrm{CO}_{2} \cdot$

Bot. Gaz. 35, pp. 83-98.

28 Dean. Proteolytic enzymes.

Bot. Gaz. 39, p. 331 .

29 Ders. Diastatischen enzyme in Pflanzen.

Ber. d. bot. Ges. Vol. 13, also Bot. ztg. 48 , No.37 \& 41

29a Drude, 0., Nanmaun, A., und Ledieu, F. Gartenbau Versuche

in Dresden 1902-03.

Jahresber. VII der "Flora" zn Dresden. 

30 Dubois, R. (See Johannsen (53) p. 65).

31 Eckerson, Sophia. A physiological and chemical study of after-ripening.

Bot. Gaz. 55, (1913) pp. 286-299. Also

E. S. R. $29, \mathrm{p} .527$.

32 Eisenberg, Elfriede. Beit. z. Kennt. der Entstehungshedingungen diastatischer enzyme in hoheren Pflanzen. Flora (1907) Vol. 97 p. 350.

33 Fermi, C. On the presence of enzymes.

Centbl. Bakt. 2 Abt. 26 (1910) pp. 330-334

34 Fisher, A. Beitrage zur Physiologie der Holzgewachee. Jahrb. f. wiss. Bot. (1891) 22, pp. 60-73.

35 Fred, E. B. Uber die Beschlounigung der Lebenstatigkeit hoherer und niederer Pflanzen durch kleine Giftmengen. Centbl. f. Bakt. 2Abt. 31 (1911) pp. 185.

35a Gerrassimow, J. Aether-Kulturen von Spirogyra. Flore 94, pp. 16-26.

36 Green, J. Reynolds. The soluble ferments and fermentation. (2nd Ed. Cambridge 1901).

37 Groom, P. Some aspects of periodicity in plants. Sc. Progg. (1911) 21, pp. 62-77.

38 Grusz, J. Über das Verhalten des diastatischen enzymes in der Keimpflanze. Jahrb. f. wiss. Bot. (1894) 26, pp. 388. 



\section{4}

39 Harshberger, J. W. Action of chemical solutions on bud

development: an experimental study of acclimatization.

Proc. Acad. Sc. Phil. 61. pp. 57-110.

40 Haas and Hill. The chemistry of plant products. Iongmans\& Co. 1913.

41 Hata. (On enzymes).

Biochem. Ztschr. 17 (1909) p. 156.

42 E. Heckel. (See Armstrong, H. E. and E. F. ).

43 Heller, A. Ueber die Wirkung atherischer oele und einige verwandten Korper auf die Pflanzen. Flora 93. pp. 1-31.

44 Hempel, J. Researches into the effects of ether on plant metabolism.

Bot. Centralb. No. 119 (1912).

45 Herzog and Meier. Ueber oxyàation durch Schimmelpilze. Zeitschr. f. physiol. Chem. 57, pp. 35-42 and $59, \mathrm{pp}, 57-62$.

46 Hill, G. R. Respiration of fruits and growing plant tissue. Cornell Exp. Station Bul. 330.

47 Howard, W. I. An experimental study of the rest period. Research Bul. No. 1, Ho. Agr. Exp. Station.

48 Iraklionow, P. P. Ueber den Einfluss des Warmbads auf die Atmung u. Keimung der ruhenden Pflanzen. Jahr. f. wiss. Bot. 51 pp. 515-1540. 

49 Irving. Effects of chloroform upon respiration and assimilation. Ann. Bot. (1911) 25, pp. 1077 .

50 Iranov, W. The action of useful and injurious stimulants on the respiration of living and dead plants. Biochem. Ztschr. 32 (1911) 74-96.

51 Jacobi, H. Ueber den Einfluss der Verletzung von Kotyledon auf das Wachstum von Keimlingen.

52 Jesenko, Fr. Rinige neve Verfahren die Ruheperiode der Holzgewdchse abzuktirzen. Ber. d. d. bot. Ges. (1911) 29, p. 273.

53 Johannsen, W. Das Aetherverfahren beim Frthtreiben, etc. (Zweite Anfl. Jena 1906).

54 Kastle, J. H. The oxidases. Bull. No. 59, Hyg. Lab., U. S. Pab. Health \& Mar. Hosp. Serv. Wash.

55 Kastle and shedd. Phenolphthalin as a reagent for oxidizing Ferments. Amer. Chem. Journ. (1901) 26. pp.526-539.

56 Klebs, Georg. Willkurliche Fntwickelungsanderungen bei Pflanzen. pp. 129-138 (Jena 1903).

57 Ueber die Rhythmik in der Entwickelung der

Pflanzen.

Bot. Centbl. 119 (1912) p. 426.

58 Koch, A. Ueber die Wirkung vom Aether und Schwefel Kohlen- 

stoff auf hohere und niedere Pflanzen.

Centralb. 1. Bakt. 2Abt. 31 pp. 175-185

59 Kochmann, H. Der Finfluss des Aethylalkohols auf der Hefegtrung. B1ochem. Ztschr. 16 pp. 391-

60 Kosnisk1, Ignacy. Die Atmung. Jahrb. f. wiss. Bot. (1901) 37 pp. 137-204

61 Kostytschew, s. Ueber den Vorgang der zuckeroxydation bei Pflanzenatmung.

2tsch. Physiol. Chem. 67. pp. 116-137

62 and scheloumow, A. On the influence of fermentation products and phosphates upon respiration in plants.

E. S. R. 26 , p. 627 Ueber die Anteilnahme der Zymase am Atmungsprozesse der Samenpflanzen. Biochem. Zeitsch. 15, pp. 164-195

64 Iakon, G. Recent investigations dealing with the annual periodicity of plants especially woody plants.

E. S. R. 28 , p. 435 .

The Florists' Exchange (1913) 36:402 Influence of nutrient solutions on the winter rest of woody plants.

Ztsch. f. Bot. 4, pp. 561-583

65a Latham, Marion E. Stimulation of sterigmatocystis by 

chloroform.

Bull. Torrey Bot. Club 32. pp. 337-351

65b Leclerc Du Sablon. (See Czapek Biochemie der Pflanzen I (1905) p.379

66 Iehmann, F. Zur Kelmung's physiologie und biologie von Ranunculus sceleratus etc.

Ber. d. d. bot. Ges. (1909) 27. pp. 476-494

67 Lepeschkin, W. W. (Effect of anesthetics upon Spirogyra)

Ber. d. d. bot. Ges. (1911) 29. p.355

68 Ibvinson, 0. Ueber Keimungs und Wachstumsversuche an

Erbsen in Losungen von Fettsauren Salzen unter

Ausschluss von Mineralsauren.

Bot. Cent. (1900) 83, p. 1, 33, 65, 97, 129, 185, 210.

69 Loew. (Concerning poison reactions).

Landw. Jahrb. 32. p.437

70 Marcel, Mirande. Influence exercée par certaines vapeurs sur la cyanogenèse vègètale Procédé rapide pour la recherche des plantes à acide cyanhydrique. Compt. Rend. (1909) 149. p.140

71 Matthai, G. C. Effect of temperature on $\mathrm{CO}_{2}$ assimilation. Ann. Bot. 16, p. 591

72 Maumene, A. (Ether forcing process).

E. S. R. 14 , p. 149

73 Mecollum. (On forcing plants). Ariz. Sta. Rpt. 1909, pp. 584-586 

74 Molish, H. Forcing plants by warm baths. Sc1. Amer. Sup. 66 (1908) E. S. R. 20, p. 626.

75 Radium as a means of forcing plants.

E. S. R. 27, p. 437

76 Morkowin, $\mathbb{N}$. Ueber den tinfluss der Reizwirkung auf die intramolekalare Atmung der Pflanzen. Ber. d. d. bot. Ges. 21 (1903) p.72

77 Muller-Thurgan and 0. Schneider. Iebensvorgtnge in ruhenden Pflanzen.

Flora 101, pp. 309-372; 104, pp. 387-446

77a Niller-Thurgan, H. Iandw. Jahresberich. Bd. 14

78 Nahokich, A. J. On growth stimuli.

Bot. CentIb. Beihefte 26 (1910) Abt. I. No. 1,pp.7-149

E. S. R. 24, p.330

79

Ueber die intramslekalare Atmung der

hoheren Pflanzen.

Ber. d. d. bot. Ges. 21, pp.467-476

80 Nazari, $\nabla$. The influence of some artificial oxydasesand of some metallic compounds on growth of wheat. E. S. R. 24, p.532

81 Niklewski. (Concerning respiration). Bot. Centralb. Boihefte 19 (1905) Abt. I, p.95

82 Osterhout. The effect of certain poisonous gases on plants.

Univ. of Cal. Pub. Bot. 3. pp. 339-340 

83 Overton. (See Johannsen (53) p.58).

84 Palladin, W. (On respiratory enzymes). Jahrb. f. wiss. Bot. 47 , pp. 431-461.

85 Die Arbeit der Atmungsenzyme der Pflanzen unter verschiedenen Verhaltnissen. Ztschr. f. Physiol. Chemie. 47 (1906) pp. 406-45I. Bildung der verschiedenen Atmungsenzyme in Abhangigkeit $v$ on dem Entwickelungsstadium der Pflanzen Ber. à d. bot. Ges. 24 (1906) pp. 97-107.

87 Parkinson, S. T. (Plant forcing). E. S. R. 25, p. 536 .

88 Pfeffer, W. Pflanzenphysiologie Bd. II 1904. Especially the chapter on Periodicity.

89 Preston, J. F. and Phillips, F. J. Seasonal variations in the food reserves of trees. Forestry Quart. 9 (1911) p. 232.

90 Pollitt, J. The influence of electricity and anaesthetics upon plants. Jour. Dept. Agr., W. Australia 15. pp.451-454.

91 Polowzow, W. Experimentelle Untersuchungen tber die Reizerscheinungen der Pflanzen. Ber. a. d. bot. cies. 26A, p. 50.

92 Puriwitsch, K. (See Butkewitsch).

93 Reinhardt u. Suschkow. Beit. zur. Starkebildung in der Pflanze. 

Bot. Centlb. Beihefte 18, p. 133.

94 Richards, H. M. and McDougal. The influence of $\mathrm{CO}$ and other gases on plants. Torrey Bot. Club 31. p. 57 .

95 Samuely, F. Oppenheimers Handbuch der Biochemie I, p. 529. (1908)

96 Sandsten, E. P. Influence of gases and vapors on growth ofplants. Minn. Bot. Studies.

97 Schroeder, H. Ueber die Einwirkung von Aethylaether auf die Zuwachshewegung. Flore 92. pp. 156-173.

98 Schmidt. The relations bet. oxidation ferments and respiration in plants.

Bot. Centlb. (1912) 119 pp. 192-493.

99 Simon, s. Untersuchungen tber das Verhalten einiger Wachstums funktionen sowie die Atmungs tatig keit der Laubhblzer whrend der Ruheperiode. Jahrb. f. wiss. Bot. 43 (1906) pp. 1-48.

100 Stoklaska, J. and Cerny. Isolierung des die anarobischen Atmungsenzyme, etc. Ber d. d. Chem. Ges. 36 pp. 622-634.

101 stuart, W. The role of anesthetics and other agents in plant forcing. Vermont Sta. Bul. 150, pp. 451-480; also 

Trans. Mass. Hort. Soc. 1909. pp.67-87

102 Townsend, C. 0 . The correlation of growth under the in-

fluence of injuries.

Ann. Bot. 11 (1897), 509-532

103 Vinson, A. E. The influence of chemicals in stimulating the ripening of fruits.

E. S. R. 22, p. 209 and 703.

104 Waters, C. E. The resting period in plants.

Plant World 6, p.154-156

105 Weber, F. Dntersuchungen ther die Wandlungen des starke und Fettegehaltes der Pflanzen ins Cosondere der Batime.

Bot. Centrlb. 113 (1910) p.166

106 Shortening the rest period of shoots by wounding and injection.

E. S. R. 27, p.22I

107 Went. Ueber den Einfluss der Nahrung auf die Enzymbildungen etc. Jahrb. f. wiss. Bot. Vol. 36.

108 White, Jean. The ferments and latent life in resting seeds. Proc. Roy. Soc. Iondon. B. 81, pp.417-442.

109 Whitten, J. C. Winter protection of the peach. Bul. No. 38, Mo. Agr. Bxp. Sta.

110 Wiegand, Karl M. Some studies regerding the biology of buds and twigs in winter. 

92

Bot. Gaz. 41 (1906) pp.373-424

111 Wiggans, C. C. Studies regarding the rest period of seeds. Thesis. University of Mo. 1913.

112 Zaleski. Zur Aetherwirkung auf die stoffunwandlung in den Pflanzen.

Ber. d. d. bot. Ges. 28 (1911) pp.292-296 







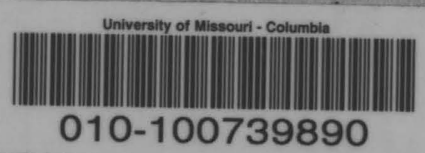

$378.7 \mathrm{M71}$

XH364

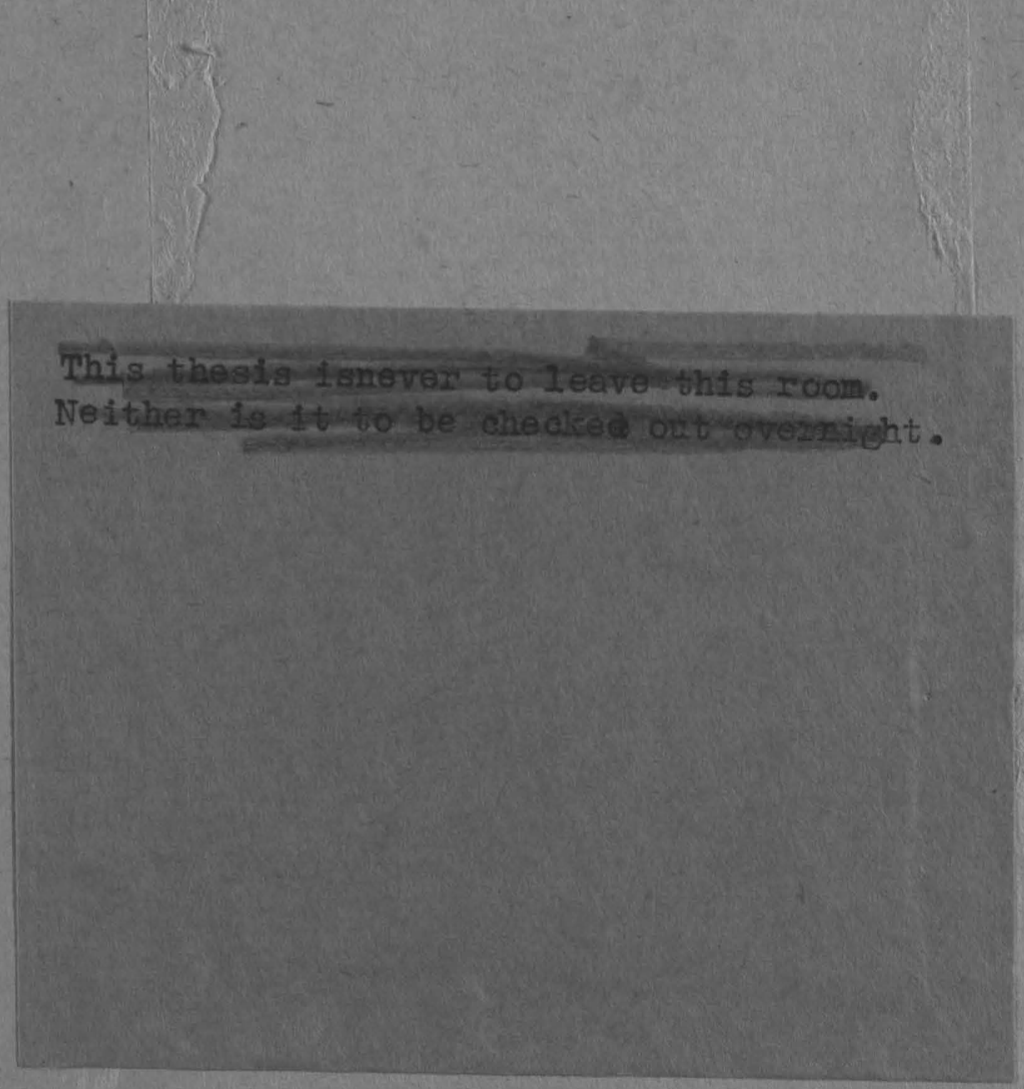


